\title{
A PHILOSOPHY OF CORPORATE CONTROL
}

\section{David C. Bayne, S.J. $\dagger$}

\section{INTRODUCTION}

In recent years the modern corporation has undergone an essential evolution. Control-the ultimate power in the policy-making hierarchy -has emerged as the central element in the corporation. With this emergence have come novel and subtle problems and an insistent need for an appropriate body of new law.

The law has approached the concept of control gingerly. At this early stage two roughly antagonistic positions have been taken by the courts, crystallized in the famous Perlman v. Feldmann ${ }^{1}$ in the midfifties and in Honigman v. Green Giant Co., ${ }^{2}$ concluded in early 1963. These prototypes set up the antithesis, and provide factual settings for the major policy questions underlying the philosophy of control.

\section{A. Perlman v. Feldmann}

Treating the position of control as a separate office in the corporate structure, C. Russell Feldmann simultaneously occupied four distinct offices in Newport Steel Corporation. He joined the office of control to that of dominant stockholder, chairman of the board, and president of the corporation.

During the Korean War steel shortage, Newport devised the "Feldmann Plan" by which the company would guarantee its customers a source of supply on the condition of interest-free prepayment for purchases. The Wilport Company, a syndicate formed by a group of end-users of steel, bought control in Newport by purchasing, at a premium, the Feldmann shares. Mr. Feldmann was to sell control through the seriatim resignation of his own board and the election of Wilport's nominees.

In a derivative action, minority stockholders of Newport sought restitution of the "illegal gains which accrued . . . as a result of the

† A.B. 1939, University of Detroit; M.A. 1946, Loyola University of Chicago; LL.B. 1947, LL.M. 1948, Georgetown University; J.S.D. 1949, Yale University; S.T.L. 1953, West Baden College. Member, District of Columbia, Michigan, and Missouri Bars.

1219 F.2d 173 (2d Cir. 1955), reversing 129 F. Supp. 162 (D. Conn. 1952), cert. denied, $349 \cdot$ U.S. 952 (1955).

2208 F. Supp. 754 (D. Minn. 1961), aff'd, 309 F.2d 667 (8th Cir. 1962), cert. denied, 372 U.S. 941 (1963). 
sale . . . of [the] . . . controlling interest in the corporation." 3 The district court refused to grant to the minority "that share of [Feldmann's] . . - profit which is attributable to the sale of the corporate power." 4 The court held instead "that the rights involved in the sale were only those normally incident to the possession of a controlling block of shares, with which a dominant stockholder, in the absence of fraud or foreseeable looting, was entitled to deal according to his own best interests." '5 The Second Circuit reversed and "remanded to the district court for a determination of the question expressly left open below, namely, the value of defendants' stock without the appurtenant control over the corporation's output of steel." " On remand the district court awarded judgment for $\$ 1,339,769.62$ plus interest. ${ }^{\top}$

Perlman v. Feldmann is a landmark ${ }^{8}$ case not only because the court held that the majority shareholder had to account to the minority shareholders, but because control itself was segregated as a separate item of sale. ${ }^{9}$

\section{B. Honigman v. Green Giant Co.}

The Green Giant Company was founded in 1903, and by 1960 had grown from a handful of employees and annual sales of some $\$ 7,000$ to sales of $\$ 64$ million and a net worth of $\$ 23,402,000$. The man behind this burgeoning growth was Edward B. Cosgrove, who with his family has controlled the company for six decades. ${ }^{10}$

At its foundation Green Giant had only one class of stock, but in 1923 the Cosgrove-dominated board amended the articles to create Class A voting and Class B nonvoting shares. ${ }^{11}$ Mr. Cosgrove possessed 26 of the 44 voting shares. ${ }^{12}$ Other than the Cosgroves, no Class B shareholder-there were 428,998 shares held by 1,250 widely

3 Perlman v. Feldmann, 219 F.2d 173, 174 (2d Cir. 1955).

4 Id. at 175 .

5 Ibid.

$6 I d$. at 178.

7 Perlman v. Feldmann, 154 F. Supp. 436 (D. Conn. 1957).

8 The Feldmam case is by no means unqualifiedly a perfect instance of the isolation of control. Later analysis will place it in its proper perspective.

9 But see Swan, J., dissenting:

The controlling block could not by any possibility be shorn of its appurtenant power to elect directors and through them to control distribution of the corporate product. It is this "appurtenant power" which gives a controlling block its value as such block. What evidence could be adduced to show the value of the block "if shorn" of such appurtenant power, I cannot conceive, for it cannot be shorn of it.

219 F.2d at 180.

10 See Record, pp. 49-70, Honigman v. Green Giant Co., 309 F.2d 667 (8th Cir. 1962) [hereinafter cited as Record].

11 See $i d$. at 52.

12 See id. at 50. 
dispersed public shareholders-possessed holdings of two percent. There was no difference between the classes except for voting rights, but the Class B stock represented 99.9 percent of the equity, earnings, and dividend rights.

By 1960 the drawbacks of the nonvoting stock became disturbingly manifest, and a recapitalization plan, ${ }^{13}$ which provided for a single new class of voting common stock, was overwhelmingly approved. ${ }^{14}$ The Class B exchanged share for share; the Class A, 1,000 to one. Class A equity increased from .01 percent to 9.3 percent, and its book value increased from $\$ 2,200$ to $\$ 2,200,000$. As a result of the recapitalization, the Cosgroves acquired for their Class A stock 26,000 of the new common shares, which, combined with what they received for their Class B holdings, gave them about 33 percent of the new common stock..$^{15}$

In a class action in the federal district court a minority shareholder sought to cancel the recapitalization plan and to set aside the issuance of the $\$ 2.2$ million premium shares. The plaintiff Honigman alleged principally that the controlling shareholders were taking a $\$ 2$ million bonus for something they did not own, since corporate control as an item of sale, if salable at all, is a corporate asset. ${ }^{16}$

The court denied relief. The crux of the decision was the court's readiness to place a premium value on the single element of control as isolated from all other values. "In these 44 shares was lodged the entire destiny of the company. It was the power of control which was lodged in these few shares which created their value... . 17 The court did not advance any reasons directly explanatory of this extra value, but stated:

No Class A shareholder could be expected to forego the power of control of a company of this size without receiving in return a consideration commensurate with the value of the control which he foregoes. It seems evident, therefore, that in light of the evidence in considering the fairness of the plan, we must commence with the premise that the $A$ shareholders in sur-

13 See $i d$. at 55 . The plan in detail is presented in the Revised Plan of Recapitalization submitted by Glore, Forgan \& Co. Id. at 327-37.

14 The court placed considerable emphasis on the importance, questionable in the light of the modern mechanics of proxy solicitation in a widely-held corporation, of the near unanimity of approval by the Class B Shareholders (The Class A shares were all cast in favor of the plan). "That fact speaks more persuasively than the arguments of those who attempt to theorize on unrealistic principles of so-called corporate democracy." 309 F.2d at 671 (1962).

15 See Record, p. 197. As a matter of fact, a more reliable calculation would seem to place the figure at 25 percent. Brief for Appellant, p. 51, Honigman v. Green Giant Co., 309 F.2d 667 (8th Cir. 1962).

16 Id. at 44.

17208 F. Supp. at 759 (1961). 
rendering their exclusive voting rights were entitled to a premium in exchanging their stock for the new voting common stock. ${ }^{18}$

The pervading spirit of the district court's opinion is best summarized in the following: "[S]o far as the charge of immoral and reprehensible conduct directed at the Class A stockholders is concerned, suffice it to say that their position in this proceeding must be judged by that which businessmen of ordinary prudence would have done under similar circumstances." 19

The court of appeals affirmed unanimously, but did not consider the fundamental issue-whether control is a salable asset. It relied on the reasoning of the lower court and concluded summarily: "We are satisfied that plaintiff has wholly failed to demonstrate that the court's failure to apply the Berle rule, that corporate control is a corporate asset, misapplied or misinterpreted the applicable Minnesota law." 20 In affirming the lower court, the court of appeals advanced negligibly the understanding of the problem of control. Although a federal court is limited in its ability to make innovations in state law, rarely has a court been presented with such an opportunity to scrutinize closely the isolated value of control as a distinct object of sale.

\section{The Problem}

Green Giant, set off against Perlman v. Feldmann, aptly poses the questions for analysis of the philosophy of control. The answer to the question of what constitutes the nature of control depends on a series of principles which extends down to the philosophical foundation on which the whole superstructure rests. The nature of control will therefore be approached in three parts: The Concept of Control; The Concept of Corporate Control; The Salability of Corporate Control.

\section{The Concept of Control}

Control is present in almost all areas of human activity. The philosophical notion of control, once discovered and analyzed, has certain distinct and definable elements which can be applied to any situation, including the corporation. There are three common philosophical elements constituting control: The Notion of Relation; The Notion of Custody; The Principle of Finality. 


\section{A. The Notion of Relation}

At the foundation of this investigation is a basic metaphysical principle: The relation between man and man entails a responsibility of the one towards the other. Each man as a human person is intrinsically possessed of a complexus of rights which must be respected by every other human being. When two people come into contact, the responsibility of respecting these rights is immediately operative, but the extent of the responsibility varies with the degree of dependency involved in the relationship. The aphorism, "Give to each his due," summarizes the essence of responsibility.

The principle that relationship begets responsibility is clarified upon reflection on the various types of human relations. The broadest categories of human relations are natural relations and assumed relations. Some of the natural relations are founded on the social nature of man himself, as is the relation of father to son. These are the relations of the greatest dependence, and hence responsibility is the most grave. There are also accidental relationships which arise almost fortuitously but which are nonetheless natural. Thus, in a tortious contract between persons, fleeting and temporary as it may be, there is the responsibility of due care. Since, however, this type of relationship is of relatively less dependency, the corresponding responsibility is relatively less grave.

Man also freely assumes many relationships. These relationships may be either formally contractual, when the parties set down the terms of the relation in the form, for example, of a constitution and bylaws, or inferentially contractual, when the responsibility arises out of justified reliance by one on another. An appropriate instance of an assumed relation is that of lawyer to client. Quite obviously this relationship may be either formally contractual or based on justified reliance. It should be clear, moreover, that these assumed relationships may be a combination of both formal and inferential elements. The formal contract adds the note of fidelity to one's word and to the natural responsibility already present without the contract.

\section{B. The Notion of Custody}

The notion of custody is also prominent in the development of a philosophy of control. The study of this special relation involves a second fundamental principle: Custody entails accountability.

This principle can best be understood by some reflections on the most common form of custody, the ownership of one's own goods. Whatever the asset of value which a person may possess, an accounting of the use and disposition of that asset will inevitably be exacted. 
This is a basic law of human economy. An adolescent betrays a sense of guilt at wasting food. A spendthrift is condemned by the community for his waste of money. One who does not properly utilize the more subtle spiritual and intellectual assets is held up for reprehension. Accounting always follows upon stewardship.

But ownership is only one type of custody. When the custody is of another's goods the governing principles do not change. Nor does the accountability diminish. The custodian must guard and keep that property as he would his own. Custody involves more than physical possession; it is a stewardship. Since there is dependence, one who undertakes stewardship of goods bears a corresponding responsibility properly to care and account for them.

As in the case of simple relations, there are two types of custody, natural and assumed. The custody of a father over a son, of the state over a citizen, is natural and essential. Custody, however, may also arise from the formal assumption of the care and stewardship of another's goods. Or it may, as with other relations, be inferred by an unspoken assumption through conduct or custom by one party or justifiable reliance by another.

It is a short step from the responsibility for the custody of another's goods, to the authority incumbent upon the exercise of that custody. The collective term "responsibility" merely expresses a congeries of duties. Yet one cannot be held to an accountability for the performance of duties without a corresponding set of rights which enable him to perform these duties. Essential to culpability for nonperformance is the ability to perform. The custodian must therefore possess whatever rights are necessary to fulfill his duties. Custody begets authority, since authority is nothing more than the total body of rights necessary to the proper exercise of the custody.

The concept of control, wherever found, is really a corollary of the concept of the authority of custody. The notion of control does not really add any new conceptual element to the combination of custody and authority. Custody expresses the idea of the assumption in trust of something of value and the duties resultant on this assumption. Authority, on its part, carries the notion of the rights consequent on these duties. Control, finally, embodies both thoughts: the dominion over another's goods and the duties and rights resultant on this dominion. In its broadest sense, control can be defined as the custody over an asset of value and the complexus of duties and rights appurtenant to that custody.

There are two further considerations stemming from the custodial aspect of control. In the first place, the extent of the custody 
determines the extent of the responsibility. If the custody is complete or partial, the responsibility will be correspondingly complete or partial. In terms of authority the reasoning is the same. The extent of the responsibility defines the orbit of authority, the rights of the office. Control over a son illustrates the point. The father's orbit of responsibility naturally extends to the total life of the son. ${ }^{21}$ The teacher at school on his part may, in an assumed relation, accept custody over the formal education of the boy, and the extent of the teacher's responsibility is thereby coterminous with that assumption. But this does not relieve the father of the ultimate obligation. So also in their respective spheres do others have orbits of responsibility to the child defined by the extent of their assumption of custody. In the end, however, the father's orbit of responsibility remains total, the others' only partial.

The second consideration is also important. The simple assumption of custody, although it defines the orbit or extent of the responsibility, says nothing about the nature of that responsibility, but merely establishes its existence and delineates its extent. It belongs to the third philosophical element constituting control, the Principle of Finality, to define the nature of the responsibility of control.

\section{The Principle of Finality}

The principle of finality-every being acts with its eye on its final goal-is a basic metaphysical concept. Finality is the all-governing norm of every activity. Expressed in terms of means to end, only that specific means may be employed which will accomplish the end.

As the end or goal determines the means, so too do these means determine the nature of the being. The nature or essence of a being must be so formed as to be able to effect the activity which is directed to the end. The end, therefore, not only determines the means, but also determines the nature that is to be responsible for producing these means. When this principle of finality is applied to the realm of human conduct it is expressed in terms of duties and rights. A duty is an obligatory end. A right is a guaranteed, inalienable means to the fulfillment of the duty-end. No one is held to a duty without the corresponding right which will permit performance. The nature and type of the right is defined exactly by the nature and type of the duty. For a congeries of duties there is an appropriate congeries of rights.

The application of the principle of finality to the concept of control leads to a definition of the nature, as distinguished from the orbit or

21 The fundamental flaw in the analogy of father-son is the free will of the son. The son, after he reaches the age of reason, is sui juris, possessed of his own destiny, rights, and duties, and hence not in the total custody of the father in this sense. His dependence is qualified appreciably, therefore. The analogy should, however, bear some fruit. 
extent, of control itself. Just as the rights-means are defined by the nature of the duty-end, so also the intrinsic nature of the position of control is defined and determined by the activity of that position. The nature of the position must be capable of using the means to the end. The opposite is also necessarily true. No act or action can emanate from the nature of any position which is not the perfect reflection of that nature or essence. Whence the adage: "You know a tree by its fruits."

Since end and means, duties and rights, activity and nature are all correlative, it is possible by studying one to know the other. Control is the complexus of duties and rights possessed by the custodian of another's goods. Close scrutiny of the purposes and objectives of control will reveal the true nature of control. Control must have the means to achieve its end, the rights to fulfill its duties, a nature conformable to its activities. The purpose, objective, end, goal of any control determines the nature or kind of that control.

By the junction of the principles derived from the Principle of Finality to the principles derived from the Notions of Relation and Custody, both the orbit and the nature of control are defined. It remains now to apply this reasoning to the concept of corporate control.

\section{The Concept of Corporate Control}

Since it is focal to the entire corporate enterprise, the newly emergent concept of control takes on a preeminent role in the formulation of a coherent philosophy of the modern corporation and in the law which reflects that philosophy.

For all its importance, however, the law has never advertently defined control. This is undoubtedly due to its relatively recent emergence and, of course, the intricacy of the concept. But as corporate legal thinking has matured, major outlines have gradually taken shape. Adolf A. Berle, Jr., gave the first substantial insights into the concept in the early thirties. ${ }^{22}$ Little progress was made for nearly a quarter century thereafter. In the mid-fifties, however, the notable Feldmann case occasioned a flurry of commentaries, the most important being those by Jennings, Leech, Hill, and Berle. ${ }^{23}$ These studies resulted in considerable progress. Their total impact was undeniable, and cer(1932).

22 Berle \& Means, The Modern Corporation and Private Property 243-46

23 Jennings, Trading in Corporate Control, 44 CALIF. L. REv. 1 (1956); Leech, Transactions in Corporate Control, 104 U. PA. L. REv. 725 (1956); Hill, The Sale of Controlling Shares, 70 HARv. L. Rev. 986 (1957); Berle, "Control" in Corporate Law, 58 Colun. L. REv. 1212 (1958). See also Katz, The Sale of Corporate Control, 38 Chicago B. Record 376 (1957); Comment, Sales of Corporate Control at a Premiun: An Analysis and Suggested Approach, 1961 DUke L.J. 554 (1961). 
tainly they advanced the earlier thinking of Berle, but there remain as yet many steps to be taken toward a definitive philosophy of control. ${ }^{24}$

Corporate control is an office, not a person. It has not reached the stage, nor need it, where it rates the title designation on an office door. But, unfortunately, the courts have not yet fully realized that it is a separate position, essentially distinct from all others. As yet it exists at law outside the group of formal members of the corporation. In the present state of the law, moreover, control is not even classified with the extracorporate parties: creditors, labor, consumers, government. But, control rightfully belongs inside the legal entity, with the shareholders, directors and officers.

In the ideal order, control as an individual entity, and not merely as an attribute or quality inhering in another entity, could exist alone. In some instances it has. It is not too difficult to imagine a situation in which a person who wielded a noncorporate power over the majority shareholder, such as a blackmailer, could hold control and yet not be a party to the enterprise. Usually, however, this is not the case. Control rarely has a completely independent existence, but instead coheres to another office.

Control, moreover, is chameleon-like, skipping from place to place in the corporate venture. Perhaps due to this opalescent nature, the law has often confused control with the position to which it was joined. Control might be thought to reside most properly in the shareholderowners, but in time of financial pressures it may shift to the bondholders or the preferred shareholders or even to the materialmen creditors. When there is complete dependence on one or two customers, control might rest in the consumer. So possibly, too, it might rest in labor or the government. Finally, effective control, as distinguished from the absolute ownership of more than fifty percent of the stock, may be held by management, founded on mere incumbency and maintained by access to the corporate mechanics of proxy solicitation, personnel, and funds. ${ }^{25}$

24 There is some promise of an intensive inspection of corporate control in the remand of Essex Universal Corp. v. Yates, 305 F.2d 572 (2d Cir. 1962). The Second Circuit, in three separate opinions, did not itself attempt a thorough exploration of the subject, but sent the matter below. "But particularly in view of our lack of knowledge of corporate realities and the current standard of business morality, I should prefer to avoid too precise instructions to the district court in the hope that if the action again comes before us the record will be generally more instructive on this important issue than it now is." Id. at 579 (Clark, J., concurring). Judge Friendly emphasized the importance of the question: "Here we are forced to decide a question of New York law, of enormous importance to all New York corporations and their stockholders, on which there is hardly enough New York authority for a really informed prediction what the New York Court of Appeals would decide on the facts here presented ...."Id. at 580 .

25 Mere influence, however great, over corporate policy must not be confused with the technical control under study. General Motors, for example, as a sole consumer, will assuredly exercise considerable influence over a "captive" supplier corporation, 
There is, moreover, a fascinating feature about the manner in which control must express itself. As powerful as it is, control is always dependent on the formality and mechanics of the shareholders' vote at the annual or special meeting. It matters not whether corporate control is found within the strict limits of the legal entity or outside. Nor does it matter whether control is based on consumer influence, management incumbency, or 100 percent stock ownership. Ultimate control must always assert itself formally, and as it were mechanically, in the vote of shares at the shareholders' meeting. Mere ownership of shares, therefore, need not mean control. Control is the power over the shares by whomever owned, or dominion over the owner of the shares. It is the last and absolute authority over corporate policy.

Neither the exact location of control, the specific source of its power, nor the necessary voting formalities are intrinsically important to an analysis of control. Once this is understood, the problem resolves itself into segregating control qua control from the various other corporate offices to which it coheres. Most of the difficulties in isolating control are traceable to a confusion between the rights, duties, and values of control qua control and the rights, duties, and values of some other office in the corporate enterprise. ${ }^{26}$

The general philosophy of control must be applied to the specific area of corporate control. The office of control is a responsibility and a complexus of duties. The orbit of this responsibility is determined by the extent of the custody of the corporation entrusted to control. The nature and kind of this responsibility is defined by the principle of finality.

The totality of these duties thus defined as to orbit and nature is the fiduciary duty of corporate control. Correlative to this complexus of duties, control possesses a complexus of rights which enables it to meet its responsibility. This complexus of rights is the authority of corporate control. Therefore, the elements of fiduciary duty and the elements of authority together constitute the formal technical definition of corporate control. Control is an office with the duties and rights inhering in the position.

even to the point of determining the percentage of corporate return on investment, but would not enter into complete top-level direction of the corporation. In the instances of noncorporate parties-consumer, labor, government-the likelihood of full, technical control is minimal.

26 Implicit here is an important question: Where should control be located? The present investigation (1) locates control where it actually is, (2) assumes for the present purposes only that it is properly so placed, and (3) analyzes the duties and rights of control wherever found-in shareholder, director, officer, creditor. In which party it belongs as a matter of right is a question which this Article does not answer. 


\section{A. The Fiduciary Duty of Control}

Fundamental to the concept of control is the basic question of the nature of its fiduciary duty. The concept of fiduciary duty, wherever found, carries answers to the essential and most vexing problems of the philosophy of corporation law. This concept has never been adequately explored. Mr. Justice Frankfurter asked incisive questions in the important Chenery case, ${ }^{27}$ but did not supply all of the answers. Other attempts have been made from time to time, ${ }^{28}$ but the broad nature of fiduciary duty still remains as probably the greatest single challenge to improvement in the evolution of modern corporation law.

The best analysis of the fiduciary duty of control lies in the successive application to the several parties of the enterprise of: the Notion of Custody, which traces the respective spheres of responsibility of each corporate office, and the Principle of Finality, which defines the nature of the responsibility.

\section{The Notion of Custody}

Within the strict legal entity there are three distinct, major spheres of responsibility, located in a descending order of authority: corporate control, the board of directors, the officers. The fourth inside party, the shareholder, has such limited responsibilities qua shareholder as to warrant only passing reference. Although control is the ultimate residuum of all responsibility and is at the top of the hierarchy, this responsibility is spread out over the entire venture in a broad pattern of delegation and subdelegation down to the lowliest participant. With each successive delegation the ambit of responsibility shrinks. Quite clearly, external parties-creditor, labor, consumer, government-also have their own responsibility, but it is of comparatively less importance.

Control has custody only, not ownership. The corporation is merely entrusted to an office, not given to an individual. The custodian must guard, guide, and nurture the corporation as if it were his own, with full knowledge that it belongs to another. Custody is conditional and indefinite in duration: conditional because it is dependent upon the will of the owner; indefinite in duration because it may cease whenever terminated by the owner.

27 "To whom is he a fiduciary? What obligations does he owe as a fiduciary? In what respect has he failed to discharge these obligations?" SEC v. Chenery Corp., 318 U.S. 80, 86 (1943).

28 Bayne, The Fiduciary Duty of Management-The Concept in the Courts, 35 U. Der. L.J. 561 (1958); Cary, Corporate Standards and Legal Rules, 50 CALTF. L. Rev. 408 (1962); Conway, The New York Fiduciary Concept in Incorporated Partnerships and Joint Ventures, 30 FordraM L. Rev. 297 (1961); Note, The Trust Corporation: Dual Fiduciary Duties and the Conflict of Institutions, 109 U. PA. L. REv. 713 (1961) ; Note, Economic Institntions and Values: Fidnciary Responsibility of Corporate Ófficers and Directors, 36 Notre DaMe Law. 343 (1961). 
Since the scope of control's responsibility is coterminous with the extent of the custody, it follows that the responsibility of control is total because the entire corporate entity has been entrusted to control. Since legislatures and courts are just awakening to the problem, this total commitment has as yet an extralegal status, unless the custody is actually in the shareholders where the law still assumes it to be.

In logical evolution each important aspect of custody, the nonownership (mere custody) and the totality (total custody), produces a major conclusion. Intrinsic to the notion of mere custody is the deduction that the benefit flowing from the custody accrues to the owner, not to the custodian.

The principle is well established that those in control of the management of a corporation are under an inherent obligation not in any manner to use their positions to advance their individual interests as distinguished from the interests they represent . . . . ${ }^{29} \mathrm{He}$ who is in such a fiduciary position cannot serve himself first and his cestuis second . . . . $\mathrm{He}$ cannot by the intervention of a corporate entity violate the ancient precept against serving two masters . . . . He cannot use his power for his personal advantage . . . . For that power is at all times subject to the equitable limitation that it may not be exercised for the aggrandizement, preference, or advantage of the fiduciary to the exclusion or detriment of the cestuis. ${ }^{30}$

Intrinsic to the notion of total custody is the deduction that the custodian acts exclusively for the entity.

The rule, inveterate and uncompromising in its rigidity, does not rest upon the narrow ground of injury or damage to the corporation resulting from a betrayal of confidence but upon a broader foundation of a wise public policy that, for the purpose of removing all temptation, extinguishes all possibility of profit flowing from a breach of the confidence imposed by the fiduciary relation. ${ }^{31}$

These two major conclusions form the keystone for the superstructure.

\section{a. Custody in Analogous Areas}

The central core of the trust relationship is identical to that of the custodial relationship of corporate control. ${ }^{32}$ Both courts and com-

29 Porter v. Healy, $244 \mathrm{~Pa}$. 427, 435, 91 Atl. 423, 431 (1914).

30 Pepper v. Litton, 308 U.S. 295, 311 (1939). (Footnote omitted.) This is a two-edged sword. Not only does the benefit go to the entity, but significantly it does not go to the custodian. "[H] must be faithful to his fiduciary duties and must not make a personal gain from performing them." Perlman v. Feldmann, 219 F.2d 173, 179 (2d Cir. 1955) (Swan, J., dissenting).

31 Guth v. Loft, Inc., 23 Del. Ch. 255, 270, 5 A.2d 503, 510 (Sup. Ct. 1939).

32 "[T] hose responsible for the Restatement of Trusts proposed the following definition or description of an express trust. It is a "fiduciary relationship with respect 
mentators have been diverted from a wholehearted adoption of trust law by a failure to acknowledge this identity. Both are relations of mere custody; in both the custody is total. Those trust rules, therefore, which apply to mere and total custody are applicable to that same custodial aspect in the corporation. The most notable difference between a trust and control of a corporation is that the trustee takes title; a person in control of a corporation does not. Title is not essential for custody. Any trust rules founded on passage of title, and therefore noncustodial, are irrelevant to corporate control. The inability to discard the differences and retain the parallels has been detrimental to an enlightened evolution of fiduciary duty.

The growth of the trust as a business form confirms this parallel. Over the three centuries of the crystallization of the corporate form, English counsel had an almost unbelievable predilection for the trust, often as a substitute for incorporation, sometimes in augmentation as a second line of insulation. ${ }^{33}$ Therefore, the basic body of trust law, which is derived from the central custodial element of the trust, may be validly employed in the law of corporate control. ${ }^{34}$ In this sense, one in control of a corporation may be described as a strict trustee. ${ }^{35}$

to property, subjecting the person by whom the property is held to equitable duties to deal with the property for the benefit of another person, which arises as the result of a manifestation of an intention to create it.' In this definition or description the following characteristics are to be noticed: (1) a trust is a relationship; (2) it is a relationship of a fiduciary character; $(3)$ it is a relationship with respect to property, not one involving merely personal duties; (4) it involves the existence of equitable duties imposed upon the holder of the title to the property to deal with it for the benefit of another; and (5) it arises as the result of a manifestation of intention to create the relationship." I Scort, TRusts 36, 37 (2d ed. 1956).

33 See Scott, The Constitution and Finance of English, Scottish and Irish Jolnt-Stock Companies to 1720 (1912); Du BoIs, The English Business Company After the Bubble Act, 1720-1800 (1938) ; Hunt, The Development of the Business Corporation in England, 1800-1867 (Harvard Economic Studies 1936).

34 The plaintiff in Green Giant contended that the Cosgrove control, by refusing any vote to the 99.99 percent equity, assumed just such a trust custody over the $\$ 23$ million in assets behind the 450,000 nonvoting shares. Brief for Appellant, supra note 15 , at $29-33$.

35 It is fascinating, in the light of all that has been and will be said, to follow Austin Wakeman Scott in the early pages of his four-volume work on trusts as he strives to penetrate to the heart of the trust relation:

The trust as a relationship. It will be noticed in the first place that we have said that a trust is a "relationship" having certain characteristics. Legal writers and courts have sometimes defined a trust as a certain kind of duty or obligation. Such a definition is too narrow. It is true that looking at it from the point of view of the trustee, there are duties owed by him to the beneficiaries; but the trust is the whole of the juridical relationship, of which the duties of the trustee are only one part. Some courts and legal writers have defined a trust as a certain kind of right which the beneficiary has against the trustee, or a certain kind of interest which the beneficiary has in the trust property, thus looking at it from the point of view of the beneficiary. While it is true that the beneficiary has the right or interest described, the trust is something more than the right or interest of the beneficiary. The trust is the whole juridical device, the legal relationship between the parties with respect to the property which is its subject matter, and includes not merely the duties which the trustee owes to the beneficiary and to the rest of 
The law of trusts has evolved a custodial rule identical to that proposed for control. The exclusive benefit of all activity within the scope of the custody belongs to the entity. ${ }^{36}$ One of the finer statements of the trust philosophy came from Mr. Justice Burton:

The solution lies in making them accountable to their corporation for their profits from such an investment, much as a trustee must account to his beneficiaries for his profits from dealings in the subject matter of his trust. This result would spring wholly from the fiduciary nature of the obligations . . . It would need no proof of a breach of trust or of the actual overreaching of anyone. ${ }^{37}$

Fletcher has discussed denomination of control as a trustee:

It has been held that if a majority stockholder actually dominates the company, although not himself an officer, through his control of a majority of the board of directors, he stands in the same fiduciary relation to the other stockholders as he would sustain if he were a director or other officer. Of course, if a majority stockholder is also a director and the president or other chief officer of the corporation, he is a trustee. ${ }^{38}$

The Restatement of Trusts lays down a rule in section 170 which could be applied validly to corporate control: "(1) The trustee is under a duty to the beneficiary to administer the trust solely in the interest of the beneficiary." 30 In a comment on the section the Reporter notes that the duty is confined to matters within the scope of the relation. The obverse of the duty to the beneficiary is expressed in section 203: "The trustee is accountable for any profit made by him through or arising out of the administration of the trust, although the profit does not result from a breach of trust." 40

the world, but also the rights, privileges, powers and immunities which the beneficiary has against the trustee and against the rest of the world. It would seem proper, therefore, to define the trust either as a relationship having certain characteristics stated in the definition or perhaps as a juridical device or legal institution involving such a relationship.

Scort, op. cit. supra note 32, at 37-38.

36 "A fiduciary relationship involves a duty on the part of the fiduciary to act for the benefit of the other party to the relation as to matters within the scope of the relation. . . . [H]e is under a duty not to profit at the expense of the beneficiary." Scotr, op. cit. supra note 32 , at 38 .

"Directors of a business corporation act in a strictly fiduciary capacity. Their office is a trust. . . . The first principal duty arising from his official relation is to act in all things of trust wholly for the benefit of his corporation." Schemmel v. Hill, 91 Ind. App. 373, 385-86, 169 N.E. 678, 682-83 (1930), quoted in Perlman v. Feldmann, 219 F.2d 173, 176 (2d Cir. 1955).

37 Manufacturers Trust Co. v. Becker, 338 U.S. 304, 316 (1949) (dissenting opinion).

3813 Fletcher, Cyclopedia Corporations § 5811, at 157-59 (rev. ed. 1961).

39 Restatement (Second), Trusts $\$ 170$ (1957).

$40 I d . \S 203$. 
Those who would incorporate the law of trusts, as limited, into the law of control ${ }^{41}$ would agree that the then Judge Cardozo, expressed the ultimate rationale of the trust obligation when he stated that:

Many forms of conduct permissible in a workday world for for those acting at arm's length, are forbidden to those bound by fiduciary ties. A trustee is held to something stricter than the morals of the market place. ${ }^{42}$ Not honesty alone, but the punctilio of an honor the most sensitive, is then the standard of behavior. As to this there has developed a tradition that is unbending and inveterate. Uncompromising rigidity has been the attitude of courts of equity when petitioned to undermine the rule of undivided loyalty by the "disintegrating erosion" of particular exceptions. ${ }^{43}$

Another parallel for corporate control exists in the law of agency. Control is an agent and the corporation acts only through agentscontrol, directors, officers.

41 Trust principles have made one clear inroad into corporation law in Section 16(b) of the Securities Exchange Act, 48 Stat. 896 (1934), 15 U.S.C. $\$ 78 p$ (b) (1958). As Judge Learned Hand commented:

Section 16(b) was passed "For the purpose of preventing the unfair use of information which may have been obtained . . by reason of his"-the "beneficial owner's"- "relationship to the issuer." The section does indeed cover trading by those who in fact have no such information, but that is true as well of dealings between a trustee and his beneficiary: "A trustee with power to sell trust property is under a duty not to sell to himself either at private sale or at auction, whether the property has a market price or not, and whether the trustee makes a profit thereby." Restatement of Trusts, $\S 170(1)$ : Comment b. All such transactions are breaches of trust, and $\$ 16$ (b) in effect made "beneficial owners" fiduciaries as directors and officers were anyway . . . The section forfeits the profits because it forbids dealings in the shares. Nobody is obliged to become a director, an officer, or a "beneficial owner"; just as nobody is obliged to become the trustee of a private trust; but, as soon as he does so, he accepts whatever are the limitations, obligations and conditions attached to the position, and any default in fulfilling them is as much a "violation" of law as though it were attended by the sanction of imprisonment.

Gratz v. Claughton, 187 F.2d 46, 49 (2d Cir.), cert. denied, 341 U.S. 920 (1951).

42 This recalls the antithetical statement of the district court in allowing the $\$ 2$-million premium to control in Green Giant. In reply to the expert witness's definition of fiduciary duty, the court remarked:

I take it you are motivated by certain ethical principles and standards which you think should be applied to a business transaction of this kind?

The Witness: This is the case, your Honor.

The Court: Rather than what the ordinary hardheaded businessman would do under similar circumstances?

The Witness: This is correct, sir.

Record, p. 300-01 (testimony of Robert W. Storrer). The court in its decision, however, concluded: "[S] uffice it to say that their position in this proceeding must be judged by that which businessmen of ordinary prudence would have done under similar circumstances." Honigman v. Green Giant Co., 208 F. Supp. 754, 762 (D. Minn. 1961).

43 Meinhard v. Salmon, 249 N.Y. 458, 464, 164 N.E. 545, 546 (1928). 
Directors of a corporation are its agents, and they are governed by the rules of law applicable to other agents, and, as between themselves and their principal, the rules relating to honesty and fair dealing in the management of the affairs of the principal are applicable. They must not, in any degree, allow their official conduct to be swayed by their private interest, which must yield to official duty. ${ }^{44}$

It seems legitimate, therefore, to borrow the strict rules of agency for the analogous law of corporate control.

The same elements of exclusive devotion to the principal within the scope of the custody, already elaborated for corporate control and found prominently in the trust, lie at the heart of the agency relationship. In trusts, agency, and control, custody is the vital factor. ${ }^{45}$ The law of agency is adamant in ascribing to the principal all benefits reaped from the relationship:

When the principal employs an agent, the law presumes that he does so in order to secure to himself the benefits of the agent's skill, experience or discretion, and to reap the fruits of the performance of the undertaking. The law presumes that he expects-and it gives him the right to expect- that the agent so employed will endeavor to further the principal's interests, and will use his powers for the principal's benefit. ${ }^{46}$

It is not a mere fortuity that the respective laws of agency, trust, and the proposed law of corporate control involve an identical set of principles, because they are founded on the same basic elements.

Corporate control is a voluntary assumption, or at least retention, of the office by a person or a group of persons which comes into being at the inception of the corporation. At the outset, control rests with the promoters and initiating shareholders. It may reside there permanently, or it may shift in time to new majority shareholders or to any

44 Perlman v. Feldmann, 219 F.2d 173, 176 (1955).

45 "Although an agent is in a fiduciary relation to his principal, as a trustee is to the beneficiaries of the trust, the two relationships have a different history and different consequences flow from them. The historians of early English law have pointed out that in the Middle Ages the germ of agency is hardly distinguished from what ultimately became the use or trust." SCotr, op. cit. supra note 36 , at 72 .

46 Mechem, Outlines of the Law of Agency $\$ 500$ (4th ed. 1952). The law of agency acts negatively as well by refusing to the agent any profits arising from the agency.

An officer is but the agent of his corporation, and in all transactions in which its interests are involved he must act for it with unselfish singleness of purpose. If in any such transaction it appears that he has acted against the interest of his corporation, the mere fact that the means used to accomplish the unlawful end would, if standing alone, be lawful in themselves will not save such officer from responsibility to account for profits thus made by him which otherwise might have gone into the coffers of his corporation. 
of the many parties in the corporate venture. The important point, however, is that control always has the custody of, and responsibility for, the corporation. The person occupying corporate control can abandon the office and thereby relieve himself of the responsibility. But mere delegation never sloughs off the ultimate burden.

\section{b. To Whom the Duty?}

It is the corporate entity which has been taken into custody. The primary duty, therefore, is to this entity. Neither this particular asset nor that, neither this constituent member nor that, has been entrusted primarily and directly to control. This does not mean, however, that there is not a genuine, although secondary and indirect, duty to the various members of the entity.

Some explanation of the meaning of the terms, "primary" and "secondary," is advisable. There is no difficulty in realizing that the total entity has been entrusted to control, and that therefore the direct and primary duty is to the corporation itself. The difficulty lies in the inclination to conclude that the duty ends there, or, at best, that the words "indirect" and "secondary" mean little or nothing. But, there is only one instance when the duty of control to the various parties, such as minority shareholders, is not fully as primary and direct as it is to the corporation. That occurs when there is a conflict between the good of the entity and the good of one of the constituent parts. Then part must yield to whole.

There is a tendency today to become entranced with the idea that the corporate entity has an existence all its own which is completely independent of its constituent parts, but a corporation, behind the legal entity, is a society of members. The fiction of the entity should never cloud the fact that the corporation is a society of persons with interests entrusted to control. The entity theory is merely a mode of expressing the idea that in any society the primary duty is to the common good and the secondary to the members. The mere injection of the word "entity" does not mean that both corporate control and the corporation itself do not have custody of the interests of the several parties to the entity.

It is the obligation of the corporate society to serve these persons. The society has a primary position only in that it must flourish if it is to perform its services to the individuals in the best way. In this way the duty to the members is indirect. The corporation has an obligation to guard, guide, and nurture the various parties which constitute it. Corporate control has the same duty to the corporation. Control in guarding, guiding and nurturing the entity fulfills its responsibility to 
the members. Only in this sense is the duty indirect and secondary. Thus, any obligation of the entity becomes also the obligation of the custodian of the entity.

\section{c. Conflict of Interest}

A stimulating discourse in Green Giant between the district court and the plaintiff's expert witness, Storer, chairman of the investment committee of The Manufacturers National Bank of Detroit, poses an arresting hypothetical instance of the head-on clash between entity and part.

The relevant dialogue began at the point at which Storer had imposed the trust duty upon Green Giant control to correct the voting deficiency in the structure, without a premium. $^{47}$ The ${ }^{-}$court interjected: "Now, then, does that fiduciary relationship continue if the stock is sold, if the class A stock is sold?" 48 Storer replied that the duty would accompany control. The court then set up the conflict of interest:

Well then, supposing in your bank it so happened that someone in connection with the Cosgrove family died and left their some 23 shares of class A stock in trust . . . . And then supposing a plan of capitalization arose somewhat comparable to this. Would you feel justified in voting the class A stock, the 23 shares that you held on a plan that provided one for one on the part of the class A stockholders? ${ }^{49}$

Storer's prompt reaction was the correct one: "If these, your Honor, were the terms of the proposition that came to me as a question to vote on it, I believe that I would vote favorably on such a proposal." 50 The court countered: "Do you think that an ordinary prudent businessman would vote in favor of such a proposal?" 51 Storer hedged for the first time: "I have no clear conviction on that. I am of mixed feelings, sir." ${ }^{52}$ The court pressed its advantage:

Well, I take it as a trustee you would have to exercise judgment and the care of the ordinary prudent man possessed of

47 This was another argument advanced by the plaintiff Honigman: Control has a fiduciary duty to correct in 1960 the defect in the capital structure which it consciously created in 1923 . The very vote originally withheld must be restored, without the payment of a personal premium of $\$ 2$ million for such restoration. Brief for Appellant, supra note 15, at 29.

48 Record, p. 299.

49 Ibid.

$50 I d$. at 300 .

51 Ibid.

52 Ibid. 
business judgment that would generally be attained by a man reasonably experienced in business . . . . You can't put into effect some individual theory of your own if you were a trustee, could you? ${ }^{53}$

At this point, unable to resolve his primary obligation as control with his secondary as trustee, Storer began to capitulate. "No, sir. I would have, in a sense, conflict of fiduciary responsibilities toward the beneficiaries of the trust on the one hand and toward the stockholders of the corporation on the other." 54 The court sensed the hesitancy.

But insofar as the beneficiaries are concerned $I$ take it that you would recognize that you would have to obtain the best business deal for them that was possible in any reorganization regardless of any fiduciary relationship that may have accompanied the Cosgroves' [sic] in their holding of this stock? ${ }^{55}$

Storer abandoned the field completely: "As you outline the situation, sir, my responsibility to my beneficiaries, sir, would be primary." With this the court administered the coup de grace: "And I take it under those circumstances you would feel justified in voting for the most favorable consideration that could be obtained by the beneficiaries even though it diluted the B stockholders' equity in the corporation?" 57 Storer closed the discourse with a dejected "Yes, your Honor." 58

In the court's hypothesis one salient fact which would have facilitated the solution escaped the expert Storer's attention. The mere interposition of a trustee between a beneficiary and a control-ownership of stock should not thereby insulate the beneficiary from the fiduciary duties of the office of control. The trustee is the beneficiary's representative. The shareholder-control unrepresented by a trustee would have the fiduciary duty of control. Represented, he continues to have the same duty through his trustee. The beneficiary's duties now become the trustee's duties. The trustee is the alter ego of the beneficiary, and must act exactly as the beneficial owner would act were he without the trust. To guide his own judgment, therefore, Storer could forget he was a trustee and conduct himself as control, with all of control's duties.

As the representative of control, the trustee owed his primary obligation to the common good of the entity, his secondary to each of the parts, one of which was the shareholding of the beneficiary. His cus-

53 Ibid.

54 Ibid.

55 Ibid.

58 Ibid.

57 Ibid.

58 Ibid. 
tody as control was far broader than his custody of the individual shareholdings. As control, a trustee must inaugurate a corporate structure beneficial to the entire entity. He could neither accept a premium for doing his duty nor favor the beneficial holder of the "twenty-three" shares at the expense of the corporation.

In the court's hypothetical, therefore, the new control, lodged in the beneficiaries and exercised by Storer as their representative, would be bound as thoroughly as its predecessor control to correct the structural defects, without exacting a premium for performing its fiduciary duty.

The possibilities for conflict are limited only by the ingenuity of the human mind. The fallible, susceptible human being who holds the office of control usually occupies another corporate office. The result is invariably a conflict of interest. If control is also the chief executive officer, the temptation is a salary in excess of true worth; if a shareholder, a selfish and reckless dividend policy; if a consumer, favored sales allocation at favored prices. And so it goes through every facet of corporate assets, prerogatives, and remuneration.

Idealistically the answer may lie in restricting the officer to the sole position of control. But this is impossible in our present corporate structure. In the end, therefore, the realistic solution is that needless conflicts must be kept at a minimum, and courts and commentators must educate the corporate community to the law of control through firm pronouncements in decision and comment. ${ }^{59}$

\section{d. Other Spheres of Duty}

Corporate control has entrusted to the board of directors a more limited custody. Most jurisdictions spell out this delegation in general terms, which recognize the traditional boundaries but also permit such leeway as particular circumstances would demand. ${ }^{60}$

59 In 1949 Nathan Lobell, then Executive Adviser to the Securities and Exchange Commission, revealed a subtle understanding of this problem:

The whole problem of corporate management is a facet of our latter-day split between ownership of wealth and the control thereof. But, if our experience at the S.E.C. has been in any sense typical, the really crucial ethical problems that have arisen in dealing with corporate management have grown out of management's ownership of a stake in the enterprise. While we once stood at the crossroads facing, on the one hand, the path of merging management responsibility with management's stake in the business and, on the other, the creation of a class of disinterested fiduciaries, we have-whether we like it or not-taken the second road. It no longer makes any sense to require that either a substantial portion of corporate wealth be owned by the management or that a substantial portion of management's wealth be invested in the corporation. The hope for effective and honest management lies in evolving a class of financially disinterested managers who accept, as part of a working code, the simple rudiments of honest politics.

Letter From Nathan D. Lobell to the Author, February 7, 1949.

${ }^{80}$ "The business of every corporation .. . shall be managed by a board of at least three [3] directors ...." MICE. CoMP. LAws $\$ 450.13$ (Supp. 1956). 
The board of directors in its turn subdelegates a yet narrower orbit of responsibility to the chief executive officer or, in a large concern, to a small group of principal officers. These officers transmit varying degrees of responsibility to others, but the major concentration of control is in the office of control itself, the board, and the officers. The limits and hierarchy of these three spheres are inviolate. If control, director or officer steps over the line he is either out of order, or is rightly or wrongly assuming a second official position.

A great danger lies in a court's refusal to recognize that control need not necessarily be joined to any other office. Indeed, control may not even be lodged in creditor, labor, consumer, or government, but may exist completely outside the corporate venture. When a court cannot identify control with a familiar office and apply the traditional fiduciary duty of that office to control, the result could be the complete failure to place liability on corporate control, if that is where it belongs in the particular case. ${ }^{61}$

The court in Feldmann was cognizant of the distinct offices, but found it unnecessary to define the various spheres since it was able to fix responsibility on Mr. Feldmann in any event. Since he was control, chief executive officer, and chairman, he was simultaneously occupying, in addition to being a dominant shareholder, all three distinct offices which are the major repositories of responsibility in the corporation. "In this case the violation of duty seems to be all the clearer because of this triple role in which Feldman appears, though we are unwilling to say, and are not to be understood as saying, that we should accept a lesser obligation for any one of his roles alone." ${ }^{2}$ Had Feldmann been corporate control and not, however, majority shareholder, chief executive, or chairman of the board, it is possible that the Feldmann court might not have held him liable.

\section{Finality: The Nature of the Duties}

Consideration of the ends of control does not prescind from the pattern of the three major spheres of responsibility. Rather, an inquiry into the nature of each office adds to the knowledge of control.

The overriding objective of the corporate entity is its own common good, which is, generally, to make profits. This primary goal

$61 \mathrm{My}$ brothers' opinion does not specify precisely what fiduciary duty Feldmann is held to have violated or whether it was a duty imposed upon him as the dominant stockholder or as a director of Newport. Without such specifcation I think that both the legal profession and the business world will find the decision confusing and will be unable to foretell the extent of its impact upon customary practices in the sale of stock.

Perlman v. Feldmann, 219 F.2d 173, 178 (2d Cir. 1955) (Swan, J., dissenting). 62 Ibid. 
is complemented by a complexus of lesser ends: the welfare of each member. The immediate purpose of the office of control is to attempt to create and maintain the best corporation possible. As the office upon which the ultimate responsibility for the achievement of this objective devolves, control must formulate and establish the overall program of corporate policy and supervise its implementation at the highest level. The extent to which control enters into detail in policy formulation and supervision varies between the extremes of a well-established, smoothly coordinated control situation and a troubled corporation in need of rehabilitation and major policy overhaul. The exact nature of corporate control shows itself most impressively in the three major divisions of policy formation.

Logically, control's first responsibility is that of providing the best possible corporate structure. Prior to incorporation, control must study the purposes and objectives of the corporation and produce articles and bylaws which will achieve the corporate goals. Control must reconcile the total common good with the obligations to the constituent members. As the years pass, control must continually review the structure to adjust to changing times. Control's next responsibility is to establish an enlightened managerial policy. If the corporation is a Saks Fifth Avenue, is it to hew invariably to a luxury line? If, on the other hand, it is an E. J. Korvette, must it remain unswervingly in the discount line or is there room in corporate policy to move into the "Fifth Avenue field"? In general, control must make top-level policy decisions including what the corporate image should be and when to economize, expand, or retrench. Control's final responsibility is to select the board of directors and to seek out competent men for the particular type of business. Control properly delegates responsibility to the directors, but must continually supervise their conduct. As with the father in the home, control can never desert final responsibility. This principle was summarized by the Feldmann court: "[T] he same rules should apply to his fiduciary duties as majority stockholder, for in that capacity he chooses and controls the directors, and thus is held to have assumed their liability." ${ }^{3}$ "Thus control is responsible for the activities of the least agent of the corporation insofar as these activities are referable to control's policy and supervisory responsibility. This duty of continual surveillance extends as well to corporate structures and managerial policy.

The board of directors, in turn, has a double objective. It must interpret the philosophy and policy of control to the officers and must formulate its own broad, albeit second-level, policy, conformable of 
course to control's norms. Both of these objectives are carried out in the three areas of policy formation previously discussed. The board might initiate necessary amendments to bylaws or articles. By resolution of the board, managerial salary policies can be established or changed, general economy programs effected, major litigation approved. Finally, the selection and promotion of top officers is a principal board responsibility.

On the third echelon, the major objective of the chief officers is the day-to-day implementation of the policy formulated by control and interpreted by the board. Except, perhaps, to make recommendations for needed changes, the officers will not be directly concerned with the corporate structure, but rather with managerial policy, the orderly administration of the business, research and development, manufacturing policy, distribution, and sales. The chief executive officer selects second level officers and major department heads. To these, of course, there will be delegation of responsibility on the lowest levels.

The principal role of the shareholder is to supply risk capital. Since the shareholder qua shareholder has been entrusted with little other responsibility, he plays a minor role in the corporation. However, for both historic and intrinsic reasons, the shareholders have a second duty to perform. In the formative days of the corporation, control was almost universally lodged with the shareholder. As a result the law has identified the two positions. Theoretically and formally this identification has endured to the present day. The shareholders, therefore, acting at their meetings, remain the conduit for the expression of the policies of control. This formalism must be observed even if the shareholder happens also to be control. The only time the shareholder speaks qua shareholder is at the annual or special meetings. However, except in the smallest corporation, policy is made, even by shareholder-control, prior to the shareholders' meeting.

This secondary function of the shareholder, however, can on occasion take on unwonted importance. When a dissident nonshareholding group determines to wrest control from the incumbent, equally nonshareholding, board, the shareholders, for a fleeting period, have the power to determine control. Momentarily and partially, control also lodges in the shareholder in the rare success of an isolated proposal deemed "proper subject" ${ }^{64}$ for shareholder action. Only on occasions like these does the formalism of the shareholders' meeting evanesce.

The objectives of the remaining parties to the venture are not relevant to the question of corporate control. Only when creditor, consumer, labor, or government also occupy the office of control do any

64 Some philosophical insights bearing on the present discussion can be gained from Proper Subject: A Symposinm, 34 U. DET. L.J. 517 (1957). 
questions arise. Furthermore, since the purposes of these four offices are so well defined, it is not difficult to segregate their duties from corporate control.

\section{B. The Authority of Corporate Control}

Corporate control is a responsibility. This responsibility, the duties inhering in the office, is the fiduciary duty of control. Set off against the duties is a correlevative complexus of rights. There should be no liability without culpability; there can be no culpability without ability; and there can be no ability without rights. In the concrete, these rights are nothing else than the great body of corporate assets placed at the disposal of the office to enable it to meet its goal. The word "assets" is used here in the broadest possible sense. It represents everything of value entrusted to control for use in achieving the objectives of the office.

Since these rights are appurtenant to the office, they are available to control at every point in the span of corporate activity. Correspondingly, however, these prerogatives are limited to official acts, and control is of course accountable for the disposition of these assets. As the New York Court of Appeals phrased it, control

was bound to account . . . for all moneys that came into his hands by virtue of his official acts . . . . The election of directors, and the transfer of the management and property of the corporation, were official acts, and whatever money he received from such official acts were moneys derived by virtue of his office, for which we think he should account. ${ }^{65}$

The utilization of these rights in official acts can be categorized in the same three areas: corporate structure, managerial policy, selection of directors and officers.

\section{The Corporate Structure}

The principal justification advanced by the court in Green Giant for giving the Cosgroves $\$ 2$ million was the bestowal of voting rights. Without voting stock, listing on a major exchange was blocked, marketability hampered, and expansion opportunities, equity financing, and diversification by merger and acquisition were made more difficult. ${ }^{B 6}$ Topnotch talent, moreover, shied away from such close control. ${ }^{67}$ All

65 McClure v. Law, 161 N.Y. 78, 81, 55 N.E. 388, 389 (1899).

68 Honigman v. Green Giant Co., 309 F.2d 667, 669 (8th Cir. 1962).

67 There was a genuine fear among top management that the death of $\mathrm{E}$. B. Cosgrove would find the control falling into undesirable hands. This fear was expressed as a desire to "promote management continuity." Record, pp. 75 (testimony of W. F. Dietrich), 100 (testimony of I. E. Felton). 
of these disabilities would be removed by the reorganization of the corporate structure, the chief feature of which was the transfer of voting rights from control to the holders of 99 percent of the corporate equity. For the purposes of a deeper investigation of the nature and duties of control it will be assumed, contrary to the facts, that there was an actual relinquishment of control by the Cosgroves. This, of course, was the assumption on which the arguments of the two courts were founded. "The argument that the family, relatives and friends of Edward B. Cosgrove would continue in control of the company is without any foundation in fact." ${ }^{88}$ The plaintiff argued that control remained where it always was, merely slipping slightly from the absolute security of absolute control to the practical security of effective control. ${ }^{69}$

The Cosgroves, occupying the office of control, had determined to pay themselves $\$ 2$ million for an improvement in the structure which good business judgment indicated was necessary or advisable for corporate and shareholder well-being. At this point the court was faced with a dilemma. Either the Cosgroves as control were paying the Cosgroves as shareholders-directors $\$ 2$ million for the performance of an official act of control, or the Cosgroves were receiving $\$ 2$ million for the sale of control without any consideration beyond the control itself. ${ }^{70}$

This dilemma is highlighted by the fact that it was the business judgment and official act of the Cosgroves which erected the deficient corporate structure in $1923,{ }^{71}$ not that this really made any difference in 1960. Whether they created the condition in the beginning or not, control was dutybound to utilize all of the rights of its office to correct any structural inadequacies. More specifically, these prerogatives (and consequent duties) consisted of the following: the study of the defective structure, the utilization of the decision of the board, the advice of in-

68 Honigman v. Green Giant Co., 208 F. Supp. 754, 765 (D. Minn. 1961).

69 Brief for Appellant, pp. 51-54, Honigman v. Green Giant Co., 309 F.2d 667 (8th Cir. 1962).

70 The district court was not prepared to admit that unadorned control was being sold by the Cosgroves for $\$ 2$ million. "After due consideration, the Court is satisfied that a fair analysis of all the circumstances justifies a finding that . . . the premium shares ... is [sic] commensurate with the benefit received by the corporation ...." The opinion makes it clear that the improvement of the corporate structure was this "benefit received by the corporation." $208 \mathrm{~F}$. Supp. at 762.

71 There is an interesting sidelight in Mr. Cosgrove's testimony as to the principal reason for his continued failure to correct the corporate structure. He had denied voting rights to the Class $\mathrm{B}$ only as a temporary expedient.

I can tell you that my attitude through the whole thing was to keep control until we were well on our way; we did not want to be raided. . . . I wanted to see good management in charge before I let go. . . Mr. Felton so emerged and I made him president. Prior to the time $\mathrm{Mr}$. Felton took over as president I had not been prepared to give voting rights to the Class $B$ stock; I had been thinking of it but I wasn't ready to do it.

Record, pp. 54-55. 
vestment counsel, the formulation of the recapitalization plan, the submission of the plan to the shareholders for approval, and the implementation of the plan. The right of control to use these facilities of its office was essential to the performance of its fiduciary duty. This raises the question of whether control should be paid $\$ 2$ million for doing its duty. ${ }^{72}$ If control is a personal asset, the Cosgroves could conceivably be justified in placing that valuation on it and pocketing the proceeds. If control is a corporate asset, however, the proceeds belong to all the shareholders rather than solely the shareholders in control.

The shift from absolute to working control cost the public investor $\$ 2$ million in Green Giant. In Manacher v. Reynolds, ${ }^{73}$ exactly the same gambit, used with a far larger firm, was worth $\$ 40$ million.

The United States Foil Company had, as Green Giant, two classes of stock, identical in every way except voting rights. The Reynolds family held all of the 540,000 voting shares and the general public $8,594,032$ nonvoting shares. Foil was actually a holding company for 50.09 percent of the stock of Reynolds Metal Company. By using these millions of public-shareholder dollars the Reynolds family was in turn able to control Reynolds Metal, the second largest integrated producer of aluminum in the country.

This was a very expensive business for the public shareholders of Foil. There were operating expenses for the holding company and extra taxation on the double dividend declarations first by Metals to Foil and then by Foil to the shareholder. These factors, plus the absence of the vote, were reflected in the value of the Foil stock on the American exchange. For many years Foil nonvoting stock had sold on the market at a full one third less than the value of the equity inter-

72 The expert witness for the plaintiff Honigman, Robert W. Storer, chairman of the investment committee of the Manufacturers National Bank of Detroit phrased this thought in these words:

In the first place, the progressive divorce between the equity interest and the voting control has arisen over the years since 1923 out of the consistent policy of causing all new common shares to be Class $B$ shares. If, as a result of this policy, the corporation is disadvantaged by the present capital structure this has arisen on the initiative and on the consistent policy of the Class A stockholders. These, through their control of the membership of the board of directors, have worked themselves gradually into a position which, to my mind, is tantamount to voting trustees with fiduciary responsibilities to their fellow stockholders. Under these conditions I believe that any action, any affirmative action which can be taken by the Class A stockholders, acting through their board to benefit the corporation, which does not result in outof-pocket cost to them, is affirmative action which they are due to take and should take vis-a-vis the Class B stockholders who are essentially the equity and the corporation here.

Record, pp. 280-81.

73165 A.2d 741 (Del. Ch. 1960), 109 U. PA. L. Rev. 887 (1961). "What is arguably an abdication of its supervisory role in the settlement perhaps flows from the court's prior conclusion that the right to any premium rested on the family's power to demand it . ..." 109 U. PA. L. REv. at 891. 
est which it represented in Reynolds Metals. This so-called discount factor amounted to approximately $\$ 140$ million.

It is understandable that the public shareholders of Foil had been agitating for the liquidation of the company. If Foil were liquidated, extra operating expenses, extra taxes, and the $\$ 140$ million discount would be eliminated. In spite of years of pleading by the public shareholders, the Reynolds family refused to discontinue the use of the public money. When litigation was finally initiated by a public shareholder, the Reynolds group came forward with a plan which differed only in details from the Green Giant plan. The Reynolds family wanted three shares of new stock for each of their voting shares, a \$40-million premium. Under the Reynolds settlement the family would own 17.4 percent of the new common which constituted operating control. Without the premium shares, they would receive 14.2 percent of the new Metals common.

Here again was the Green Giant problem. Was the corporate structure of Foil the best for the entity and its members, or did it serve only one party who happened also to be in control? Did control exercise the prerogatives and rights of its office in the performance of its fiduciary duty to the entity and to all its members? Did it have the right to use these corporate assets for its own personal benefit?

The court stated the problem exactly:

The issue is whether the A may fairly agree with the $B$ to take appropriate action to remove the discount in return for premium [sic] amounting to one-third of the discount. ${ }^{74}$ . . This being so, the A shareholders hold the key with which to unlock the "discount" treasure chest for the B. No other factor being present, they may demand a reasonable premium for the use of their key. ${ }^{75}$

The key was improvement of the corporate structure. This was a corporate asset, a right entrusted to control to enable it to perform its duties. The use of this key should have been a routine operation, a fundamental fiduciary duty of control, and the Reynolds court realized this. "[T] he hard fact of life is that the proposed action by the A [the alteration of the corporate structure] is an indispensable prerequisite to the realization of any benefit by the $B$ from the elimination of the discount." 76 The minority shareholder contended that control violated its fiduciary duty; that the violation "consisted of their exacting the 3 for 1 premium as their price for letting 'their' board act on a

74165 A.2d at 750.

$75 I d$. at 754.

76 Id. at 750. 
merger . . . ."77 The court, however, approved the settlement and was "hesitant to say that the settlement was so unfair that it should be rejected." 78

One conclusion emerges from Green Giant and Reynolds. Corporate control in each case was faced with the responsibility of providing the best possible corporate structure for the entity and its constituent members. At the disposal of control was the entire corporate apparatus with which to fulfill this responsibility. The utilization of these assets should have been no more than the performance of the fiduciary duty of control.

\section{Managerial Policy}

The corporate assets at control's disposal for the performance of managerial duties range from the picayune perquisites of the officeyachts, clubs, secretaries, and chauffeurs-to the determination of important policies of purchase and sale, of initiation of litigation and declaration of dividends. Entrusted with a profusion of rights and prerogatives, the temptation is intense to regard these corporate means to the corporate end as private powers. Although they clearly belong to the corporation in the beginning, they somehow mysteriously become transformed into personal privileges and chattels.

Corporate control has a daily array of lesser corporate assets placed at its disposal in the performance of its duties. Some of these, of course, are included contractually, directly or indirectly, as acknowledged elements of its just compensation. With the remainder and greater majority, however, control faces a double difficulty. First, they may not even be appurtenances of the office of control at all, but rather set aside for the use of other offices within the corporate entity. Secondly, if they are properly at its disposal, control must remember that they are nonetheless not a personal possession. It may not appropriate them altogether, divert them to purely personal use, or preempt assets unnecessary in quantity or quality.

It is a relatively simple matter for a person in control to commandeer the plant maintenance crew, and have them build a new sun porch to his home or a sprinkling system in his garden. There are many more subtle areas, such as credit cards, business vacations, town clubs, country clubs, and hunting lodges. Unless these privileges are acknowledged forms of compenssation, they should be categorized as direct appropriation of corporate assets or a saddling of the corporate budget with expenses unwarranted by the objectives of the entity. The 
excess may be either one of quantity or quality. The principle of finality draws a definite line as to both. The means must conform to the end.

The Feldmann litigation highlighted a far more serious preemption of corporate assets in the managerial policy field. The plaintiff described the premium of $\$ 1.3$ million over the intrinsic value of $\mathrm{Mr}$. Feldmann's shares as "compensation for the sale of a corporate asset, a power held in trust for the corporation by Feldmann as its fiduciary." 79 The Second Circuit concluded that "in a time of market shortage, where a call on a corporation's product commands an unusually large premium, in one form or another, we think it sound law that a fiduciary may not appropriate to himself the value of this premium." 80 The court could scarcely have expressed the fundamental philosophy more aptly. Here was a corporate means, the managerial policy of product distribution to customers, to the attainment of the overall corporate end, the prosperity of entity and members.

The parallel with Green Giant when viewed from this particular aspect is noteworthy. The Cosgroves had a duty to provide Green Giant with the best possible corporate structure. Feldmann had a duty to pursue the most enlightened management policy for the benefit of Newport.

Perhaps it would be more accurate to regard Feldmann from a different viewpoint. One could concentrate on the benefits, the interestfree prepayments, inuring to the corporation instead of the policy which produced the benefits. From either aspect, however, both the gain from the policy and the policy itself belonged to the entity, not to Feldmann personally; therefore, he could hardly sell them. ${ }^{81}$ The court properly held Feldmann to a fiduciary duty to formulate managerial policy for the sole benefit of the corporation.

[T] he responsibility of the fiduciary is not limited to a proper regard for the tangible balance sheet assets of the corporation, but includes the dedication of his uncorrupted business judgment for the sole benefit of the corporation, in any dealings which may adversely affect it. . . . Although [this] . . . is particularly relevant to Feldmann as a director, the same rule should apply to his fiduciary duties as majority stockholder, for in that capacity he chooses and controls the directors, and thus is held to have assumed their liability. ${ }^{82}$

79 Periman v. Feldmann, 219 F.2d 173, 175 (2d Cir. 1955).

$80 \mathrm{Id}$. at 178.

81 Thus, the $\$ 1.3$ million paid Mr. Feldmann could be viewed as a present accumulation of future interest-free prepayments which would otherwise have later benefited corporation and shareholders.

82219 F.2d at 176. (Emphasis added.) 
The report which outlined the Green Giant plan of recapitalization also presented a revealing list of so-called "Advantages of Control." 83 The list presents an excellent example of the possibilities for personal appropriation of corporate assets in the field of managerial policy. An introductory paragraph restates the popular misconception that these prerogatives of control belong personally to the individual not the office. $^{84}$

In considering the advantages of control to Class A stockholders we are not primarily concerned with advantages from the possible illegal actions. However, there are many possible actions which might be adverse to the Class B stockholders but are either legal or on the borderline. Specific areas of such action are as follows. ${ }^{8 \overline{5}}$

Among the "specific areas of such action," the report lists one which is peculiarly related to the Feldmann-type subversion of managerial policy:

Entering into contracts with suppliers or agents owned by the Class A stockholders could be advantageous. However, opportunities to do this are probably limited and the advantages small. Contracts not made on an arms-length bargaining basis would certainly be open to attack. ${ }^{86}$

Reference was made passim by various officers of Green Giant that such opportunities for adverse contracts could occur, for example, in the purchase of tin cans, labels, and unprocessed vegetables. ${ }^{87}$

83 Record, pp. 338-40. The report was prepared by Glore, Forgan \& Co.

84 The answer filed by the defendants in Porter v. Healy, $244 \mathrm{~Pa} .427,91$ Atl. 428 (1914), expresses this attitude: "The price fixed for the stock itself was $\$ 165$ per share . . and the additional compensation that we were to receive for parting with our control was an entirely private business matter. . . . In the sale of our stock, and in all that we did in connection therewith, we acted solely as individual owners, .. and never did any act in connection therewith as directors." Id. at 434, 91 Atl. at 431 . The court, however, held that "all money thus made belongs either to the corporation, or, in a case like the present, in common to its shareholders . . . ." Id. at 437,91 Át1. at 432 .

85 Record, p. 338. (Emphasis added.)

80 Id. at 339. An analysis of the implications of these "Advantages to Class A Stockholders of Control" is intriguing. Three distinct conclusions stand out:

(1) It would be unjust were any inferences of reprehensible past conduct made from these statements. L. E. Felton, president of Green Giant, testified on crossexamination that "The Class A stockholders did not enter into any adverse contracts with the company." Id. at 86. (2) There was no reason to suppose Green Giant control itself would indulge in the future in these suggested practices. (3) What Glore, Forgan, and hence Green Giant control, did have in mind was that a purchaser might indulge in these possible practices, might pay Green Giant for the opportunity to avail itself of these advantages, and that Green Giant control therefore deserved $\$ 2$ million because it held the key to unlock these treatsures to such a purchaser.

$87 I d$. at 87 (testimony on cross-examination of I. E. Felton). 
Numerous instances can be cited of advantages which are redolent of the recapitalization report and the Feldmann allocation of sales. ${ }^{88}$ In the classic case of Sher $v$. Sandler, ${ }^{89}$ one partner bought out the other and thereby guaranteed to himself the undisclosed advantages of a marked increase in corporate business. The court ordered restitution. In addition, control might traffic in customer lists, or, as the Feldmann court suggests, in the sale "of corporate good will" ${ }^{90}$ or latent productive capacity. However, these are all patently corporate assets.

L. E. Felton, President of Green Giant, mentioned the use of the corporate trademarks as "one other advantage of the $A$ stock." ${ }^{11}$ This would be equally true of such other rights as patents, copyrights, and the like. A prolific source of litigation has been appropriation by control of the benefits to an acquiring corporation of a net operating-loss deduction which can be carried over as a tax credit against future earnings. ${ }^{92}$ In Keely $v$. Black corporate control accepted a substantial gratuity for relinquishing territorial rights of a small local telephone company to the Bell system. ${ }^{93}$ In the well-known cases of Young v. Higbee $\mathrm{Co}^{94}$ and Clarke v. Greenberg ${ }^{95}$ pending litigation was compromised. All these are examples of the appropriation by control of valuable corporate assets in the field of managerial policy.

Porter v. Healy ${ }^{96}$ and Commonwealth Title Ins. \& Trust Co. v. Seltzer ${ }^{97}$ are two classic opinions which support the proposition that it is the essence of the duty of control to formulate and implement an enlightened managerial policy. Both opinions, written by Justice Moschzisker of the Supreme Court of Pennsylvania, describe the duties

88 The following are instances in which control has appropriated corporate assets in the purchase or sale of goods: Price v. Standard Oil Co., 55 N.Y.S.2d 890 (Sup. Ct.), modified, 77 N.Y.S.2d 686 (App. Div. 1945) (sales); Bliss Petroleum Co. v. McNally, 254 Mich. 569, 237 N.W. 53 (1931) (purchase); Durfee v. Durfee \& Canning, Inc., 323 Mass. 187, 80 N.E.2d 522 (1948) (extra charges exacted through dummy middleman set up by a director); Remillard Brick Co. v. Remillard-Dandini Co., 109 Cal. App. 2d 405, 291 P.2d 666 (Dist. Ct. App. 1952) (corporate profits siphoned off through wholly-owned sales corporation). In the Deep Rock case, Taylor v. Standard Gas \& Elec. Co., 306 U.S. 307 (1939), contracts adverse to Deep Rock were set up by the Byllesby control group providing for management and supervision, rentals, and heavy-interest loans. These machinations are detailed in Bayne, The Deep Rock Doctrine Reconsidered (pts. 1-2), 19 ForohaM L. Rev. 43, 152 (1950). Another gross instance was the adverse management and supervision contract imposed on the Mayflower Hotel by the Hilton control group. Mayflower Hotel Stockholders Protective Comm. v. Mayflower Hotel Corp., 193 F.2d 666 (D.C. Cir. 1951).

89325 Mass. 348, 90 N.E.2d 536 (1950).

90 Perlman v. Feldmann, 219 F.2d 173, 178 (2d Cir. 1955).

91 Record, p. 87. (1956)

92 See generally Jennings, Trading in Corporate Control, 44 CAI.IF. L. REv. 1, 16

9391 N.J. Eq. 520, 111 At1. 22 (Ct. Err. \& App. 1920).

94324 U.S. 204 (1945).

95296 N.Y. 146, 71 N.E.2d 443 (1947).

$96244 \mathrm{~Pa} .427,91$ Atl. 428 (1914).

$97227 \mathrm{~Pa} .410,76$ Atl. 77 (1910). 
of directors of corporations, but their analysis is equally applicable to control, wherever it exists.

The principle is well established that those in control of the management of a corporation are under an inherent obligation not in any manner to use their positions to advance their individual interests as distinguished from the interests they represent . . . ${ }^{98}$

In the Porter case the corporate asset involved was a public utility franchise. The Porter court concluded its opinion with a trenchant analysis of the duties of control:

Although the stock of one who is a director of a corporation is his individual property, to be dealt with as he pleases, and to be sold for such a price as he may be able to get for it, either in association with others or alone, yet, his official position is not his individual property in any sense, and he has no right, either directly or indirectly, to use it for his own selfish ends; when he does so, and thereby derives a gain that can be reasonably traced to such an abuse, all money thus made belongs either to the corporation, or, in a case like the present, in common to its shareholders . . . ${ }^{99}$

In the Seltzer case the "effort to get control . . . was solely for the purpose of forcing the sale of its property . . . ." 100 The court held corporate control to "an inherent obligation not to in any manner use their positions to advance their individual interests as distinguished from the interests of their corporation." 101

"The director of a corporation is a trustee for the entire body of stockholders, and by assuming the office he undertakes to give his best judgment in the interests of the corporation in all matters in which he acts for it, untrammeled by any hostile interest in himself or others; and all secret profits derived by him in any dealings in regard to the corporate enterprise must be accounted for to the corporation." 102

\section{The Selection of Directors and Officers}

The sixth ${ }^{103}$ and last of the Green Giant report's "advantages" evaluates the third category of corporate prerogatives:

98 Porter v. Healy, $244 \mathrm{~Pa} .427,435,91$ At1. 428, 431 (1914).

100 Commonwealth Title Ins. \& Trust Co. v. Seltzer, 227 Pa. 410, 415, 76 Atl. 77,

78 (1910).

101 Id. at $416-17,76$ Atl. at 79.

102 Id. at 417, 76 Atl. at 79, paraphrasing Byrd Coal \& Iron Co. v. Humes, 157 Pa. 278, 287-88, 27 Atl. 750, 752 (1893).

103 Other advantages suggested by the report are: obtaining control to secure a capital gain by liquidating the company, arranging mergers and consolidations advantageous to the controlling persons' outside interests, cutting or eliminating dividends to avoid personal income taxes, granting stock options. Record, p. 339. 
From a practical standpoint, it would seem that the chief advantage of control is the right to elect the principal officer of the corporation and thereby to obtain the largest salary that could not be attacked in the courts plus other perquisites of the office including such things as stock options, pensions, insurance coverage, et cetera. ${ }^{104}$

The right of control to appoint major officials is undoubtedly one of the chief means of promoting the ends of the corporation. ${ }^{105}$ Over sixty years ago the New York court in McClure v. Law properly characterized the law on the subject:

The election of directors, and the transfer of the management and property of the corporation, were official acts, and whatever money he received from such official acts were moneys derived by virtue of his office, for which we think he should account. ${ }^{106}$

So also Judge Swan dissenting in Feldmann:

Consequently, if the price paid for Feldmann's stock included a payment for voting to elect the new directors, he must account to the corporation for such payment, even though he honestly believed that the men he voted to elect were well qualified to serve as directors. He cannot take pay for performing his fiduciary duty. ${ }^{107}$

Whatever may be the particular prerogative or right encompassed in the authority of control-whether it concerns corporate structure, managerial policy, or the selection of directors and officers-that power is not a personal possession or privilege but an incident of office which remains in the office.

\section{The Remuneration of Corporate Control}

\section{Monetary Remuneration}

An adequate compensation is the reward for the proper utilization of the rights and the performance of the duties of custody. Remuneration is proportioned to performance. The compensation due to control is relative to the manner in which control employs the prerogatives of the office. This is the principle of quid pro quo so assiduously protected by the law. 
The delicate balance between performance and emolument is not peculiar to the office of control alone. No party to the corporate venture should be compensated for performance of the duties of another office, or for work he should have done but never did. The labor done determines the remuneration.

Four primary tenets must be emphasized: the office possesses the duties; the office possesses the rights; the officeholder receives the emolument; upon the relinquishment of the office, the successor receives the duties, rights, and emolument.

Two popular fallacies have resulted from failure to apply these tenets: that the person can somehow continue to be compensated even after he quits control; that some forms of compensation become permanent possessions of the individual and are not perquisites attached to the office.

The failure to distinguish corporate assets at the disposal of the office from personal possessions of the individual is the first great source of error plaguing the concept of control. The second major problem is confusion between compensation for labors actually performed and compensation for work never done-either before, during, or after the period of employment.

Theoretically, and also practically, corporate control is the most important and most valuable party to the enterprise. The contributions of the top-level control group to a complex modern corporation may appear slight in point of time and physical energy expended, but they are undeniably the prevailing and crucial element in the success or failure of the corporation. The compensation of control must match these enormous benefits. This fact has produced a marked antithesis in the present extralegal status of control. On the one hand, control deserves great rewards which should be distributed through appropriate and acknowledged channels. On the other, control cannot be permitted to retain unowned assets and unearned recompense. This antithesis burdens the law with a paradoxical challenge: to establish standard and acceptable processes for adequately compensating control for its vast labors, and to outlaw both the individual's personal appropriation of official, corporate assets and the officeholder's personal retention of unjust compensation either during or after the tenure of office.

Meeting the first challenge would help to eliminate the second. Were control properly compensated, the temptation to appropriate would diminish. Ideally, there should be two distinct categories of control compensation: direct emolument awarded in the traditional manner and indirect benefit flowing to control as an individual through his second position in the enterprise, such as shareholder, bondholder, or officer. 
Control should not be forced to secure a just recompense by the temporary occupancy of an acknowledged, traditional position. This does not mean, however, that if control is actually performing the duties of two offices, it should not be paid for both. The point is that whatever else a person in control does he should receive the proper rewards for the labors of control.

The facts in Green Giant provide an apt illustration of the double deficiency which the law must correct. Mr. Cosgrove was ostensibly being paid one salary for the performance of three offices. There was little harm in this, however, since the $\$ 70,000$ per annum plus collateral benefits seemingly compensated him for all his labors. It would be healthier, however, to attribute the sum to its specific sources. ${ }^{108}$

Another facet of the Green Giant facts provides an instance of the temptation facing the person in control when he quits the office. Although the recapitalization report had taken "all factors into account," ${ }^{109} \mathrm{Mr}$. Cosgrove's annual income of $\$ 70,000$ was an important element in establishing his share of the $\$ 2$ million premium. The report capitalized and reduced to present worth an assumed salary of $\$ 75,000$ per year over a 20 - to 25 -year period which produced a valuation of a million dollars, just for the salary. ${ }^{110}$ Since Mr. Cosgrove's major allegation was that he was relinquishing the office of control there is no perceptible reason why he should continue to be compensated for the office. This salary should rightfully belong to his successor.

108 The failure to denominate properly the compensation for each of $\mathrm{Mr}$. Cosgrove's three offices (control, board chairman, and chief executive officer) occasioned him some unnecessary and unjustified embarrassment during the Green Giant litigation. For six to eight years Cosgrove continued to receive approximately $\$ 70,000$ per year even though he had not occupied the presidency during this period. Perhaps he was properly apologetic in that he had not taken any reduction in his remuneration upon relinquishment of the presidency, but he nonetheless performed the valuable services of control and board chairman, for which he certainly deserved a substantial recompense. Had his various emoluments been listed over the years with the proper designations (e.g., control: $\$ 30,000$; board chairman: $\$ 10,000$; president: $\$ 30,000$ ) he would have been spared this uneasiness (had he, of course taken an appropriate, e.g., $\$ 30,000$-per-year, cut). He declared:

I attribute my job as Chairman of the Board to years of experience with the company and not my ownership of class A stock [He undoubtedly meant control]. I don't consider what I am being paid excessive for my years of experience; a fellow who starts with three employees and $\$ 7,000$ worth of sales and runs it into a company with $\$ 64,000,000$ worth of sales has obviously had a lot of experience.

Record, p. 57.

109 See id. at 122-23 (testimony of C. S. Vrtis), 216-17, 236, 242 (testimony of F. W. Leich).

$110 \mathrm{It}$ is revealing to compare this capitalization of the salary with the statement in the Glore, Forgan Report: "[T] he chief advantage of control is the right to elect the principal officer of the corporation and thereby to obtain the largest salary that could not be attacked in the courts plus other perquisites of the office . . . " Id. at 340 . 


\section{Nonmonetary Remuneration}

Prestige in the community is an inestimable factor in total remuneration. Remuneration in the form of spiritual values can be the most powerful incentive offered to control. Strict altruism manifested in a desire to benefit corporation, community, and society is rarely a motivation and hence an emolument to control. But the desire to express organizational ability, to feel deeply the sense of accomplishment in a complex job well done can constitute very satisfying compensation for control.

One might hastily conclude that these nonfinancial forms of compensation do actually become the permanent possession of the individual. The contrary is true. As with the salary, they go with the office and to the officeholder. The opportunity to organize, the power, the prestige, all belong to the corporation. They may be paid out to the officeholder as remuneration, but they are not his to keep or to sell to another. They are to be returned to the corporation at the close of tenure and passed on to his successor in office.

\section{Control's Motivation}

Almost universally, control coheres to another position in the enterprise. Since this is so, all the great efforts of control toward benefiting the entity have the immediate effect of enhancing the value of each constituent part, including control's. This is the primary motivation to control's activity and the chief remuneration. Mr. Cosgrove described this emolument of control in a very earthy way: "Because I control the company where most of my money sits. My estate is essentially Green Giant Company." 111

If corporate control is also a shareholder, as was Mr. Cosgrove, his indirect reward will consist in an appreciation of the value of the stock and increased dividends. If it is a member of management his month-to-month efforts will yield higher salary, greater prestige, power, and satisfaction. These emoluments are the principal and substantial-and altogether legal-compensation of corporate control.

The three concepts-fiduciary duty, authority, remuneration-will answer the questions posed by the salability of control. Has control an independent value? Who owns it? May it be sold? By whom? For whom? To whom? The answers to these queries will not advance appreciably the thinking thus far outlined, but they will explore these principles from different vantage points and give new perspective to the fundamentals. 


\section{The Salability of Corporate Control}

The sale of corporate control highlights the subtle issues of the concept. There is no impelling necessity to buy and sell control in order to analyze it, but a buyer and a seller take a hard look at the object of sale. The motivating desires of the buyer are evaluations of at least one highly interested person. "It is sometimes said that value is the price on which a willing and informed buyer and seller, neither under compulsion to trade, would meet." 112 The expert Brandi in Reynolds voiced the same thought: "I think the value which you can obtain for something such as control ${ }^{113}$ is an important factor in determining the value of relinquishing something." 114 This was the as-

112 Application of Behrens, 61 N.Y.S.2d 179, 183 (Sup. Ct. 1946), aff'd, 271 App. Div. 1007, 69 N.Y.S.2d 910 (1947).

113 One of the inexplicable holdings in Reynolds remained equally unexplained in Green Giant. Both courts based their decisions on the questionable assumption that control actually changed hands. This assumption, of course, was fortunate from the standpoint of the development of a philosophy of control. The discussion would be circumscribed indeed were the only question the difference in value between absolute and working control.

The facts, however, in both cases were to the contrary. In both, incumbent control, at the most, relinquished absolute control for virtually impregnable working control. To this day control is yet to shift to the public groups who paid the $\$ 40$-million and $\$ 2$-million premiums.

In Green Giant a former board member stated: "The control is still going to rest in the Cosgrove family." Record, p. 263. The fact is that Robert Cosgrove recently moved from vice-president (at $\$ 40,000$ per annum) to fill his father's place as chairman.

In Reynolds the court remarked, "the $\mathrm{A}$ are not giving up voting control because they will still have working control of Metals after the merger." Manacher v. Reynolds, 165 A.2d 741, 751 (Del. Ch. 1960). This raises the practical question (assuming that control has a legitimate sale value): How valuable is the exchange of absolute for effective control? The major difference between the two rests in the possibility of a successful challenge by dissidents. The Reynolds court appreciated this issue: "The court has substantial doubt that the relinquishment of absolute voting control but the retention of working control has a value 'close' to that which would be involved in sale of absolute control to a willing buyer." Id. at 753 .

The court later made a remarkable statement in the light of its allowance of the full $\$ 40$-million premium:

The court frankly does not believe there is any explicit evidence of the value of relinquishing absolute control which would justify the conclusion that a particular figure would be fair to the A and B. For the reasons already stated herein, I do not believe the basis for Mr. Brandi's testimony as to the value of relinquishing control is sound here. I must frankly say that were I to view the case apart from the stockholder action I would conclude that the premium is excessive. I say this because the discount factor is not a "value" which can be attributed to the A. Moreover, the A will retain working control. I do, however, recognize that the $A$ may fairly exact a premium as a condition to the relinquishment of absolute voting control.

Id. at 754. The court nonetheless concluded: "The approval of a settlement requires the court, inter alia, to exercise a business judgiment. Under such an approach the court would be hesitant to say that the settlement was so unfair that it should be rejected." Id. at 755 .

The practical question-beyond the major question of the salability of full controlpersists: Are $\$ 40$ million and $\$ 2$ million fair prices for the slip from absolute to effective control?

114 Manacher v. Reynolds, 165 A.2d 741, 753 (Del. Ch. 1960). 
sumption underlying the recapitalization reports "Advantages of Control." 115

A dangerous fallacy lurks in this value-to-a-buyer norm. Professor Leech put his finger on it: "A person is in a 'valuable' position so long as someone is anxious to bribe him." 116 He meant that the willing and informed buyer might be motivated by a litany of illegitimate desires. Such a buyer might not be "primarily concerned with advantages from the possible illegal actions. However, there are many possible actions which might be adverse to the [public] stockholders but are either legal or on the borderline." 117 Foolish and vain desires, moreover, ought not be classed as bona fide values. One must sift the legitimate from the questionable.

The salability of control nonetheless affords an admirable concluding dissection of the concept. Competent thinkers have placed a legitimate sale value on control, and although Judge Swan, in Perlman v. Feldmann, adduced no support for his stand, he stated: "Concededly a controlling block of stock has greater sale value than a small lot." 118

Analytically, the salability of control resides in the intrinsic value of the elements of the object of sale, the ownership of these elements, the sale itself, the viewpoints of the buyer and the seller.

\section{A. Evaluating the Elements of Control}

The Person of the Officholder. Ever since Berle's remarks in the thirties, control has more or less been loosely connected in the public mind with the individual person or persons who happen to occupy the office. Certainly, however, the person occupying the office would not be considered one of the elements constituting control itself. The intrinsic value of control does not include the personal qualities of excellence of the officeholder. The incumbent may be astute, sagacious, intelligent, and scrupulously honest, but these valuable qualities do not increase or decrease the inherent value of control in itself. The person must be eliminated as an element of value.

The Fiduciary Duty of Control. This congeries of duties is a responsibility. It is conceivable that a responsibility has a value in and

115 Record, p. 338. Counsel for Green Giant also relied heavily on evidence that a third party had at some time previous engaged in preliminary negotiation toward the purchase of Cosgrove control for a sum reputedly "in excess of $\$ 2$ million." Brief for Appellees, pp. 3, 13, Honigman v. Green Giant Co. The court used this, with other factors, as evidence "that the market of the Class A shares far exceeded the market value of the same number of Class B shares . . . ." Honigman v. Green Giant Co., 208 F. Supp. 754, 757-58 (D. Minn. 1961).

116 Leech, Transactions in Corporate Control, 104 U. PA. L. Rev. 725, 757 (1956).

117 Record, p. 338.

118 Perlman v. Feldmann, 219 F.2d 173, 180 (2d Cir. 1955) (dissenting opinion). 
of itself, but most people would disagree. But, for the sake of argument, it is advisable to consider the fiduciary duty as one element of value.

The Authority of Control. Without doubt the rights and prerogatives of the office are the chief value of control. The corporate assets at control's disposal constitute a vital core of value intrinsic to corporate control.

The Remuneration of Control. Could any of the many forms of compensation be considered as constituents of the value of control? The past emolument already paid to the officeholder for labors performed is obviously no longer a present object of value to control. As to future emolument, control has at hand for distribution all the forms of future compensation: salary and bonuses, power and prestige. Arguably, this is an element of value.

The Office Itself. Since the person holding the office is not a value factor, does the office itself have an intrinsic value? The fiduciary duty, the rights and prerogatives, and the power to award compensation all inhere in the office, and it therefore follows that every element of value belongs to the office. But the office alone, shorn of duties, rights, and future emolument is absolutely worthless. All of the value, therefore, resides in these three elements. The office itself is valuable only for what it can accomplish.

\section{B. Ownership of the Office}

The officeholder is one of the two possible owners of control. Of the five possible value elements of control, the person and the office without its parts have already been eliminated. The question is whether the officeholder owns any of the parts.

The fiduciary duty of control certainly does not follow the person in control when he retires. The corporation still needs fulfillment of these duties by his successor. In addition, the rights and prerogatives of control are corporate assets to utilize in the fulfillment of the corporate needs. Moreover, the corporation, not the person in office, has in the corporate coffers money, power, prestige, which it may bestow on the corporate agents who labor for the firm. These emoluments are paid to, not owned by, the individual in control. Future emolument remains for future disbursal.

If ownership of control is not in the officeholder, it must reside in the corporation. Just as the office of chairman, of president, of chief operating officer are parts of the corporation, so too is control an integral part of the corporate structure. One generally does not say 
that a whole "owns" its part, but nonetheless the corporation owns all its offices, including control.

As the corporation owns the offices, it also possesses the right to fill them. The principal invariably selects the agent. The corporation appoints its agents also, and control is the chief corporate agent. It is true that the peculiar constitution of the corporation often renders it necessary, or at least possible, for incumbent corporate control, as principal agent, to make the selection of its successor. This is merely another of control's routine and standard administrative duties, even though it happens to be its last one. It is for such acts that it has been regularly compensated. Although corporate control finds itself duty bound to name its successor, this does not mean that it should receive a premium for being a worthy servant.

A director is privileged to resign, but so long as he remains a director he must be faithful to his fiduciary duties and must not make a personal gain from performing them. Consequently, if the price paid for Feldmann's stock included a payment for voting to elect the new directors, he must account to the corporation for such payment, even though he honestly believed that the men he voted to elect were well qualified to serve as directors. He cannot take pay for performing his fiduciary duty. ${ }^{119}$

The law has always proscribed traffic in corporate offices. The law may not have analyzed minutely the impropriety in the sale of an office, nor reasoned the matter through to the essentials of duties, rights and remuneration, but an innate sense of right order led the law to the correct rule, broad as it was.

Trustees of corporations owe duties to others besides themselves; they have been placed in a position of trust by the stockholders, and to those stockholders they must be faithful. It is a violation of that trust for them to be bought out of office. They may resign when they please, but they must not make profit or benefit to themselves in the matter of such resignation. ${ }^{120}$

The case of Porter $v$. Healy founded its decision "on the theory that a majority of the directors of the corporation cannot "barter their offices for individual gain." "121 The court granted recovery to the plaintiffs because "the defendants sold this control as their individual estate and received a special compensation for it." ${ }^{122}$ The court con-

$118 \mathrm{Id}$. at 179.

120 Forbes v. McDonald, 54 Cal. 98, 100 (1880).

121244 Pa. 427, 434, 91 Atl. 428, 431 (1914).

122 Id. at 433, 91 Atl. at 430. 
cluded with the categorical statement: "[H] is official position is not his individual property in any sense . . . ."123 Even Hill, who condones a premium payment for control admits: "It can hardly be doubted that a sale of control of American Telephone and Telegraph Company at an excessive price, though purporting to be a sale of a 'controlling block' of shares, would be similarly condemned as the delivery of naked power for a private consideration." 124

The conclusion seems inescapable that the ownership of the office rests in the corporation, and is in no way the personal possession of the incumbent, transient, officeholder.

\section{Analysis of the Sale}

Characteristically, the actual sale of control is embodied in the formality of a concomitant sale of a relatively large block of stock. It is a rare day when naked control, completely isolated, is passed for a price by the seriatim resignation of the incumbent board. This would be entirely too bald and would clearly fall under the interdict against the barter of the office. The sale therefore is camouflaged behind the sale of the stock. Beyond the legal reasons, this artifice is also prompted by a subliminal realization that the office is not for sale. This cloak lessens the subconscious embarrassment attendant on unadorned traffic in control.

Courts and commentators have been deeply vexed with the task of segregating the true value of the stock from the amount allegedly paid for bare control. ${ }^{125}$ No tenable reason precludes an attempt at such separation. The many pertinent considerations-market value, book value, future earnings, liquidation, investment value ${ }^{128}$ - undoubtedly figured in the final computation by the district court on remand ${ }^{127}$ in Feldmann. There the shares were selling in the over-the-countermarket below $\$ 12$; the book value was $\$ 17.03$; the Wilport syndicate paid $\$ 20$. The court determined that $\$ 1,339,769$, the excess above $\$ 14.67$ per share (plus interest from the date of sale), constituted the illicit amount "attributable to the sale of the corporate power." 128

${ }^{123} I d$. at 437,91 Atl. at 432 .

124 Hill, The Sale of Controlling Shares, 70 Harv. L. REv. 986, 998 (1957).

125 Leech, stupra note 116 , at 819-20, discusses in detail the factors involved. See also Perlman v. Feldmann, 219 F.2d 173, 178-80 (2d Cir. 1955) (Swan, J., dissenting); Jennings, Trading in Corporate Control, 44 CALIF. L. REv. 1 (1956).

126 See Application of Behrens, 61 N.Y.S.2d 179 (Sup. Ct. 1946), aff'd, 271 App. Div. 1007, 69 N.Y.S.2d 910 (1947); in re General Realty \& Utils. Corp., 29 Del. Ch. 480, 52 A.2d 6 (Ch. 1947); Jennings, supra note 143, at 1.

127 Perlman v. Feldmann, 154 F. Supp. 436 (D. Conn. 1957).

128 Perlman v. Feldmann, 219 F.2d 173, 175 (2d Cir. 1955). 
The Pennsylvania Court in Porter v. Healy also succeeded in differentiating the licit stock value from control (although admittedly it was a simple chore since the defendants conceded the difference).

In considering this contention it is to be noted that the defendants not only admitted in their testimony that the "control fund" was separate and apart from the price received for their stock, but the answer filed by them, in speaking of the sale of their holdings, expressly avers, "the price fixed for the stock itself was $\$ 165$ per share . . . and the additional compensation that we were to receive for parting with our control was an entirely private business matter.. . . In the sale of our stock, and in all that we did in connection therewith we acted solely as individual owners, . . . and never did any act in connection therewith as directors." 120

Thus differentiated, the Fealy court ordered the return of "the control fund' of $\$ 86,830$." 130

Feldmann and Healy do not mitigate the difficulties attendant on the isolation of the licit value from the "control fund," but they do indicate that such segregation is possible. However, the difficulty in separating the true value of the stock from the amount paid for control should not alter the conclusion that once the legitimate stock value has been separated, there is nothing in the subject matter of the sale which justly belongs to the selling officeholder. There remains only the office.

\section{Viewpoints of the Buyer and the Seller}

Any remaining queries conceivably can be answered by viewing the sale through the eyes of buyer and seller. This approach should also further differentiate legitimate from illegitimate buyer desires.

Fortunately, the courts long ago eliminated the gross cases of illegitimate control purchase. ${ }^{131}$ To this extent the problem has been

129 Porter v. Healy, 244 Pa. 427, 434, 91 Atl. 428, 431 (1914).

$130 \mathrm{Id}$. at 436,91 Atl. at 431.

131 The parallel cases, Gerdes v. Reynolds, 28 N.Y.S.2d 622 (Sup. Ct. 1941) and Insuranshares v. Northern Fiscal Corp., 35 F. Supp. 22 (E.D. Pa. 1940), presented blunt examples of illegal sales and consequent, identical looting of liquid treasuries through the sale of control. In Insuranshares, management had working control (25 percent), sold its entire interest at $\$ 3.60$ per share (with a market, over the counter, at $\$ 1$ to $\$ 1.25)$, and handed over the company and its investment portfolio through the seriatim resignation of the board. The company was then stripped of its assets and left a mere shell.

The court in Insuranshares rejected the claim that "the transfer . . . was simply a sale of stock, the passing of control being merely a normal concomitant. . . . This view .... is fundamentally wrong. If the whole record be read, I do not see how the transaction can be considered as anything other than a sale of control, to which the stock sale was requisite, but nevertheless a secondary matter." Id. at 24.

On this assumption the court commented on the role of control:

Those who control a corporation, either through majority stock ownership, ownership of large blocks of stock less than a majority, officeholding, 
simplified and narrowed to the subtle and apparently unassailable instances.

In pursuing the thesis of this Article there may be a tendency to regard all buyer desires and motives as illegitimate. To the contrary, an honest entrepreneur will have high-minded and commendable objectives for taking over control. Foremost among these, and patently laudable, is the legitimate purpose of improving the corporation, and the value of his own interest, by his enlightened management. The dissident minority shareholder might be genuinely and understandably concerned about the future welfare of his investment. Possibly the best protection for his interests is the assumption of control by one competent to improve the company.

The buyer must be encouraged in these aspirations. However, four questions arise and their answer should eliminate this last major concern. Should the buyer pay a premium for this purpose? Does such a premium, if paid, belong to the seller? By whom is the premium paid? Is this payment in fact a premium at all?

These questions are too inextricably intertwined to be answered separately. The answer is that the buyer of control is actually not paying any premium at all. Consider, in two different factual situations, the buyer's objectives to enhance the corporation and his investment.

If the buyer has sufficient capital he can best achieve his goal by buying the entire enterprise- 100 percent of the outstanding stock. This removes any obstacles to his management. In a total purchase the full price is paid for every legitimate value of the corporation, physical assets, cash balances, accounts receivable, goodwill, and control, together with the desired opportunity to supervise entity and investment. In a 100 percent purchase, moreover, the buyer pays each individual shareholder his proper proportion of the total, including the proration of that amount of money specifically referable to control. Thus the holder of control, with 51 percent of the stock receives 51 percent of the value, to the buyer, of the corporation.

If, on the other hand, the buyer does not have sufficient funds, he may be able to purchase only working control. The basic equities, however, have not changed. The fact that a part, rather than the whole, has been purchased, does not alter the respective rights of all the shareholders. As each had a proportioned share of the whole, so each has a proportioned share of the part. The person in control should not now

management contracts, or otherwise, owe some duty to the corporation in respect of the transfer of the control to outsiders. The law has long ago reached the point where it is recognized that such persons may not be wholly oblivious of the interests of everyone but themselves, even in the act of parting with control....

Id. at 25 . 
exact 71 percent of the value of the corporation. He is selling no more than before, and if he owns 51 percent of the stock, he should receive only 51 percent of the total corporate value. The buyer must, therefore, prorate to all of the shareholders any sum greater than the seller's proportionate interest in the corporation. With such a proration, there would be no premium at all.

But if the buyer is forced to pay the seller more than the seller's prorated share of the total corporate value, he is paying the right amount to the wrong person. ${ }^{132}$ When the person in control sells at a premium, he is denying other shareholders an opportunity to sell their shares at a proper and higher price, and is appropriating the difference. To say that the so-called premium belongs to all the shareholders is to say that the premium belongs to the corporation. This completes the circle again, since the premium is for the office and the office belongs to the corporation.

Another aspect of the sale demands consideration. Apart from the question of whether the outgoing officeholder has a right to a premium, who should pay the premium? There are three possible payers: the corporation itself, the shareholder, or a third-party purchaser. It should be noted, however, that the corporation itself is indistinguishable from all the shareholders. There is no difference in effect between the shareholders paying the premium directly and the corporation paying it out of surplus, since the effect of the corporate action is the interest of all the outstanding shareholdings. If by chance one class of stock bears the entire cost of the premium, for example, by a reduction of the stated value of the class, there is a double inequity: the payment of the undeserved premium to control and the discrimination in levying the whole from one class rather than prorating it.

If the office of control is a corporate asset, then the third-party purchaser should pay the premium to the corporation. Therefore, any payment by a third party to an outgoing officeholder is in effect an indirect payment into the corporate till and then out of the till to the outgoing control. From this aspect, all three cases-payment by corporation, shareholder, third party-represent a deprivation of money due and owing the corporate entity.

It is possible that some of the misunderstanding surrounding the sale of control can be attributed to the latent, but important, factor of legitimate but unpaid compensation. When the hardheaded businessman is conscientiously convinced that as outgoing control he should receive something more than the bare market value of his shares on a

132 In some cases, another motive for the payment of a premium on the purchase of control could be the buyer's desire to avoid the expense of a proxy fight. This situation could be solved by the passage of more imaginative corporate laws to reduce the amount of time, money, and energy now necessary to oust poor control. 
unit basis, he is perhaps merely claiming remuneration for years of unrequited labor. Control, especially in the formative years of corporate life, should be remunerated. In the very years when the corporation is least able adequately to compensate control, the greatest demands are made on his initiative, imagination, and energy. Only unusual foresight could establish an exact formula of payment contingent on success, or a formal plan of future and retroactive remuneration. It is not unnatural, therefore, that the individual desires to settle these deferred accounts at the time he surrenders control. Unfortunately, he may term the account "something extra," which it really is not. Even more unfortunately, especially for the attempts to understand fully the salability of control, he may refer to this deferred compensation as a just and legitimate sale value of control. Merely because the payment coincides with the sale of the majority stock interest, it is not a sale value of control. Nor, for that matter, does it preclude its payment at the time of quitting control. But it does mean that deferred compensation, or a contingency-on-success payment, must not be confused with a legitimate sale value of control. It is essentially unrelated to the sale of control. ${ }^{133}$

There are other factors which might aid in the explanation of many misconceptions. In so complex a concept as control the mind cannot quite shake off the accretions of years spent in the subliminal assumption that control was a personal possession, not an office. Generations of honest businessmen have accepted without question the hard facts of business life that control could be sold and the premium pocketed by the seller.

The primary factor which has entrenched this fallacy in the American mind is historical. In the early years the American corporation was predominantly one-man or closely held. In an incorporated partnership, or a privately held corporation, those in control were the corporation. The only public concern was for the creditors. But when the public entered the scene, as with Green Giant, the matter became otherwise. The corporate assets remained, but the corporation was no longer a personal possession. For twenty years Green Giant was rightly regarded as the Cosgrove family estate. It is a traumatic, perhaps im-

133 The Internal Revenue Service has possibly so confused deferred compensation with a premium for control. "Occasionally a large block may be held to be worth more than the quoted price per unit multiplied by the number of shares in the block. This is true of a block carrying with it the control of the corporation." RIA FED. TAX CoORDINATOR, §P-6211(5), at 42171. See also §P-6211(1), at 42169-70; $\S \mathrm{P}-6215.4$, at $42169-70$. There is, however, nothing in Treasury Regulations, rulings, or tax cases to warrant the conclusion that tax law recognizes a premium value as such. Treas. Reg. \$\$20.2031-2(e), 25.2512-2(e) (1963); Rev. Rul. 59-60, § 4.02(g), 1959-1 Cum. Bull. 237; James Couzens, 11 B.T.A. 1040 (1928); Estate of Telling, 3 CCH Tax Ct. Mem. 652 (1944). 
possible, feat to admit abruptly that the public now has a 99 percent equity in that estate.

A second factor contributing to the fallacy is the subconscious impulse to assert ownership of an enterprise when a person contributes appreciable time, energy, and intellect to that enterprise. One forgets that the compensation received over the years has presumably satisfied the obligation of the employer. The error is human: "So much of it is I, it should be mine." A competent cook will often express twentyfive or thirty years of assiduous labor in terms of "my kitchen."

Part of the problem can be attributed to widespread and accepted moral laxity. Even the most upright and conscientious, especially after years of incumbency, may come to regard every season as open season on the multitude of lesser corporate assets. The progress from de minimis appropriation to major embezzlement may be long-term and gradual, but nonetheless effortless. The federal district court in Backus v. Finkelstein ${ }^{134}$ summed up the situation:

It is possible that defendants had no accurate knowledge or clear conception of their duties, or of what the law required of them as managing officers and owners of the majority of the stock in the corporation in question. It is at least charitable to take this view, and it may be according to the fact. It is not difficult to understand how in a somewhat vague and blind way they may have reasoned that such success as attended the corporation was largely due to their individual efforts, and therefore that they should reap the reward to the exclusion of all other persons. This may explain their course, but it fails entirely to justify or excuse. . $^{135}$

\section{Conclusion}

Corporate control is truly a corporate asset. All shareholders are entitled to share equally in this asset. No individual or group of individuals may lawfully appropriate this asset solely for personal benefit.

Weaknesses withal, this principal proposition seems tenable. Undeniably, considerable refinement yet remains. It is hoped that the courts and commentators will mull over these thoughts, strengthen the weaknesses, and hand on to the next generation a more perfect concept of control.

13423 F.2d 357 (D. Minn. 1927).

135 Id. at 359. 